\title{
The role of enteric neurons in the development and progression of colorectal cancer
}

Citation for published version (APA):

Rademakers, G., Vaes, N., Schonkeren, S., Koch, A., Sharkey, K. A., \& Melotte, V. (2017). The role of enteric neurons in the development and progression of colorectal cancer. Biochimica et Biophysica Actareviews on Cancer, 1868(2), 420-434. https://doi.org/10.1016/j.bbcan.2017.08.003

Document status and date:

Published: 01/12/2017

DOI:

10.1016/j.bbcan.2017.08.003

Document Version:

Publisher's PDF, also known as Version of record

Document license:

Taverne

Please check the document version of this publication:

- A submitted manuscript is the version of the article upon submission and before peer-review. There can be important differences between the submitted version and the official published version of record.

People interested in the research are advised to contact the author for the final version of the publication, or visit the DOI to the publisher's website.

- The final author version and the galley proof are versions of the publication after peer review.

- The final published version features the final layout of the paper including the volume, issue and page numbers.

Link to publication

\footnotetext{
General rights rights.

- You may freely distribute the URL identifying the publication in the public portal. please follow below link for the End User Agreement:

www.umlib.nl/taverne-license

Take down policy

If you believe that this document breaches copyright please contact us at:

repository@maastrichtuniversity.nl

providing details and we will investigate your claim.
}

Copyright and moral rights for the publications made accessible in the public portal are retained by the authors and/or other copyright owners and it is a condition of accessing publications that users recognise and abide by the legal requirements associated with these

- Users may download and print one copy of any publication from the public portal for the purpose of private study or research.

- You may not further distribute the material or use it for any profit-making activity or commercial gain

If the publication is distributed under the terms of Article $25 \mathrm{fa}$ of the Dutch Copyright Act, indicated by the "Taverne" license above, 
Review

\title{
The role of enteric neurons in the development and progression of colorectal cancer
}

\author{
Glenn Rademakers ${ }^{\mathrm{a}}$, Nathalie Vaes ${ }^{\mathrm{a}}$, Simone Schonkeren ${ }^{\mathrm{a}}$, Alexander Koch ${ }^{\mathrm{a}}$, Keith A. Sharkey ${ }^{\mathrm{b}}$, \\ Veerle Melotte ${ }^{\mathrm{a}, \mathrm{c}, *}$ \\ ${ }^{a}$ Department of Pathology, GROW - School for Oncology \& Developmental Biology, Maastricht University Medical Center, Maastricht, The Netherlands \\ ${ }^{\mathrm{b}}$ Hotchkiss Brain Institute and Snyder Institute for Chronic Diseases, Department of Physiology and Pharmacology, Cumming School of Medicine, University of Calgary, \\ Calgary, Alberta, Canada \\ c Department of Clinical Genetics, University of Rotterdam, Rotterdam, The Netherlands
}

\section{A R T I C L E I N F O}

\section{Keywords:}

Enteric nervous system

Colorectal cancer

Neurotransmitters

Intestinal inflammation

Tumor microenvironment

\begin{abstract}
A B S T R A C T
The enteric nervous system (ENS) is the intrinsic neural network of the gastrointestinal tract, which is essential for regulating gut functions and intestinal homeostasis. The importance of the ENS is underscored by the existence of severe gastrointestinal diseases, such as Hirschsprung's disease and intestinal pseudo-obstruction, which arise when the ENS fails to develop normally or becomes dysregulated. Moreover, it is known that enteric neurons are involved in intestinal inflammation. However, the role of the ENS in colorectal cancer (CRC) carcinogenesis remains poorly understood, even though processes like perineural invasion and neoneurogenesis are important factors in CRC. Here we summarize how enteric neurons are affected during CRC and discuss the influence of enteric neurons, either direct or indirect, on the development and/or progression of CRC. Finally, we illustrate how the ENS could be targeted as a potential anti-cancer therapy, establishing the ENS as an integral part of the tumor microenvironment.
\end{abstract}

\section{Introduction}

Over the last twenty years, the enteric nervous system (ENS), the complex neural network embedded in the wall of the gastrointestinal (GI) tract, has become an increasingly important topic in the study of developmental gastrointestinal diseases, functional GI disorders and even diseases of the central nervous system, such as Parkinson's disease $[1,2]$. The ENS, also referred to as the 'second brain' or 'minibrain' $[3,4]$, consists out of an extensive network of enteric neurons and enteric glial cells organized in ganglia interconnected by nerve fiber bundles $[5,6]$. Enteric nerve fibers innervate the entire thickness of the gut wall, and are in close contact with the intestinal epithelium. Enteric ganglia are arranged in two major plexuses: the submucosal plexus and the myenteric plexus [7]. The submucosal plexus in humans is composed of an inner plexus located at the border of the muscularis mucosae and the submucosa, and an outer plexus that lies adjacent to the circular muscle. The submucosal plexus is in all species exclusively located in the small and large intestines, but not found in the stomach [8]. The myenteric plexus, on the other hand, is found along the length of the entire GI tract and is located between the circular and longitudinal muscle layers $[8,9]$. The ENS controls every function of the GI tract via signaling involving both enteric neurons as well as enteric glial cells [1,5,10-13]. When GI disease severely impacts the ENS, gut functions are seriously compromised, which can even be life-threatening [14]. Although the ENS has been extensively studied in the context of developmental, inflammatory and functional diseases, its role in the development and progression of colorectal cancer (CRC) is understudied and poorly understood.

\footnotetext{
Abbreviations: 5-HT, serotonin; Ach, acetylcholine; AOM, azoxymethane; ATP, adenosine triphosphate; CAC, colitis-associated cancer; cAMP, cyclic adenosine monophosphate; CGRP,

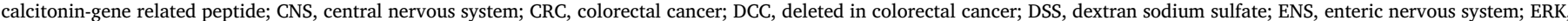

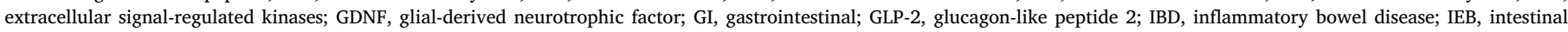

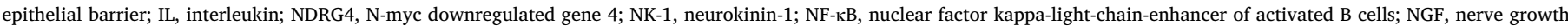

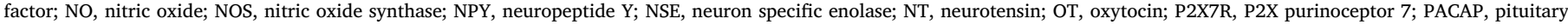

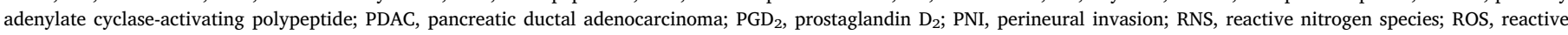

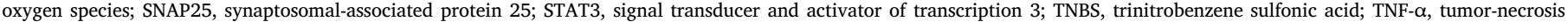
factor- $\alpha$; VAMP-3, vesicle associated membrane protein 3; VIP, vasoactive intestinal peptide; YAP, yes-associated protein

* Corresponding author at: Dept. of Pathology, GROW - School for Oncology and Developmental Biology, Maastricht University Medical Center, P.O. Box 616, 6200, MD, Maastricht, The Netherlands.

E-mail address: veerle.melotte@maastrichtuniversity.nl (V. Melotte).
} 
CRC is the third most common cancer worldwide with estimated 1.4 million new cases per year [15]. Additionally, with a mortality rate of $8.5 \%$, corresponding to 700,000 people, CRC is also the third most common cause of cancer death in the world [15]. The highest incidence and mortality of CRC is found in developed countries in North America and western Europe, with an increasing incidence found in countries which are becoming more westernized $[16,17]$. Initially, the development and progression of CRC was considered to be caused by the accumulation of genetic and epigenetic events $[18,19]$. Nowadays it has been recognized that the tumor microenvironment plays a key role in carcinogenesis [20]. Within the tumor microenvironment a large variety of cell types has been identified, including endothelial cells, pericytes, fibroblasts, myofibroblasts, immune cells and nerve cells $[20,21]$. The cells in the microenvironment are able to promote cancer cell growth, proliferation, survival, invasion/metastasis, and angiogenesis via the release of many different growth factors and cytokines [21-24]. While some cell types of the microenvironment, like endothelial or immune cells, have been extensively studied and show promising results as therapeutic targets in CRC, the putative role of the ENS in the development and progression of CRC is largely unknown. Recently, different landmark papers described the importance of neurons as critical microenvironmental determinants of cancer progression in prostate [25], pancreatic [26], skin [27] and gastric [28,29] cancers. In addition, it has been shown that enteric neurons have an important role in gut homeostasis and regeneration [12,29] which address a central role for enteric neurons in colorectal carcinogenesis. Most mechanisms described so far, by which enteric neurons interact with epithelial and tumor cells to promote gut homeostasis and/or malignant growth and invasion, involve the release of neuromodulators. In this review, we give a brief account of the physiology of the ENS and explore the current knowledge of enteric neurons on epithelial homeostasis/inflammation, and their involvement in the development and progression of CRC.

\section{The major functions of the enteric nervous system}

Enteric neurons number between 400 and 600 million in humans and 1.2 million in mice; the sheer size of the ENS suggests it is important $[1,30]$, and this is borne out by developmental studies showing that its absence has lethal consequences [14]. Many subtypes of enteric neurons have been identified based on differences in morphology, electrical properties, projections and function $[1,6,31]$. It is now widely accepted that these subtypes of enteric neurons are functionally relevant and are able to control motility, and regulate intestinal permeability, secretion, blood flow and other activities of the gut $[1,12,13]$.

The ENS plays an important role in the regulation of gastrointestinal motility via a peristaltic reflex circuit. The reflex is initiated by the release of enteroendocrine hormones, notably serotonin (5-HT) or direct mechanical stimulation of intestinal primary afferent neurons. Intestinal primary afferent neurons project to local interneurons which innervate motor neurons upstream and downstream of the origin of the stimulus. The ascending interneurons activate excitatory motor neurons in order to initiate contractions of the smooth muscle via the release of acetylcholine (ACh) and substance $\mathrm{P}$, while downstream interneurons activate inhibitory motor neurons which release nitric oxide (NO) and vasoactive intestinal peptide (VIP), to relax the descending portion of the gut. Together this pattern of upstream contraction and downstream relaxation establishes a pressure gradient that leads to propagation of luminal content and forms the basis of propagated gastrointestinal motility [32-34]. Segmental motility of the intestine, where local movements occur to aid digestion, has also been well defined $[35,36]$.

Intestinal epithelial barrier function is tightly regulated and controls the permeability of the intestines which is essential to prevent microbial products, microbes, antigens and other harmful substances from leaving the lumen and entering the bloodstream. ACh and substance P released by enteric neurons causes an increase in paracellular and transcellular permeability [12,37], while VIP reduces intestinal permeability [38]. Therefore VIP is able to balance the effects caused by permeabilityincreasing factors like ACh, substance P, but also inflammatory mediators and pathogens $[38,39]$. Intestinal barrier function is regulated by enteric neurons in the short term through post-translational modification of the myosin light chain phosphorylation, but also over more extended periods of time through changes in the expression of tight junction proteins [38-40].

The ENS also regulates secretion of $\mathrm{H}_{2} \mathrm{O}$, electrolytes and mucus, and plays a role in fluid exchange between the intestinal lumen and the gut mucosa. Active secretion and fluid exchange is initiated by intrinsic enteric reflexes [13]. Stimulation of intestinal primary afferent neurons activates secretomotor neurons which initiate secretion by the release of ACh, VIP, adenosine triphosphate (ATP), and substance P, while inhibition of the secretomotor neurons is mainly regulated via the sympathetic nervous system and by interneuronal-released somatostatin $[41,42]$.

Overall, less is known about the role of enteric neurons in the regulation of proliferation, repair, wound healing and blood flow. Even though it is well known that the enteroendocrine peptide glucagon-like peptide 2 (GLP-2) exerts trophic effects on the mucosal epithelium, it remains to be determined which other neuromodulators are involved in this process. Several studies have suggested that ACh, substance $P$ and VIP are important stimulators for epithelial cell proliferation although contradictory evidence indicates that VIP also has antiproliferative effects [43-46]. Other neuromodulators that take part in the regulation of the epithelium/epithelial homeostasis are 5-HT, which is involved in epithelial growth and [47] endocannabinoids have a role in mucosal healing [48]. Finally, enteric neurons can regulate blood flow within the gut in order to maintain a proper balance between the absorption of nutrients and fluid exchange [12,42]. Acetylcholine released by vasodilator/secrotomotor neurons interacts with the blood vessels to release NO from the endothelium hereby inducing vasodilation [42]. Guan et al. showed that also GLP-2 is able to stimulate blood flow. As GLP-2 receptors are localized on neurons expressing NO and VIP, it is suggested that these neurotransmitters act as additional regulators for blood flow [49]. Calcitonin gene-related peptide (CGRP) and substance $\mathrm{P}$ are also neurotransmitters with vasodilatory effects, but the signaling of these transmitters in the context of vasodilatory modulation originates from splanchnic primary afferent neurons which have their cell bodies located in the dorsal root ganglia [50]. However, signaling from the sympathetic nervous system (SNS) for blood flow is also essential for intestinal vasoconstriction. The SNS stimulates vasoconstriction via $\alpha 1$-adrenergic pathways in particular induced by norepinephrine/noradrenaline (NE) [51]. Additionally, dopamine, the precursor of NE, and neuropeptide $\mathrm{Y}$, which is regarded as a co-transmitter with $\mathrm{NE}$ in the SNS, exert vasoconstrictor effects, although several lines of evidence indicate that these transmitters can also attenuate vasoconstriction depending on the binding to specific subtypes of receptors [52-54].

This brief overview of the functions of the ENS outlines many of the major transmitters and provides important background about the importance of the ENS. Currently most of our knowledge of the ENS in intestinal pathophysiology is based on studies on genetic ENS diseases, like Hirschsprung's disease, and on intestinal inflammatory conditions, like IBD. This needs to be considered when examining the role of enteric neurons and enteric neurotransmitters in intestinal inflammation and CRC.

\section{Linking gut inflammation, a predecessor for CRC, and the ENS}

The ENS plays a pivotal role in orchestrating the inflammatory processes in the gastrointestinal tract. Margolis et al. showed how an altered enteric neuronal density can contribute to the severity of gut inflammation. They treated two different mouse models, each characterized with an altered number of neurons with 2,4,6-trinitrobenzenesulfonic acid (TNBS) and dextran sodium sulfate (DSS) to 


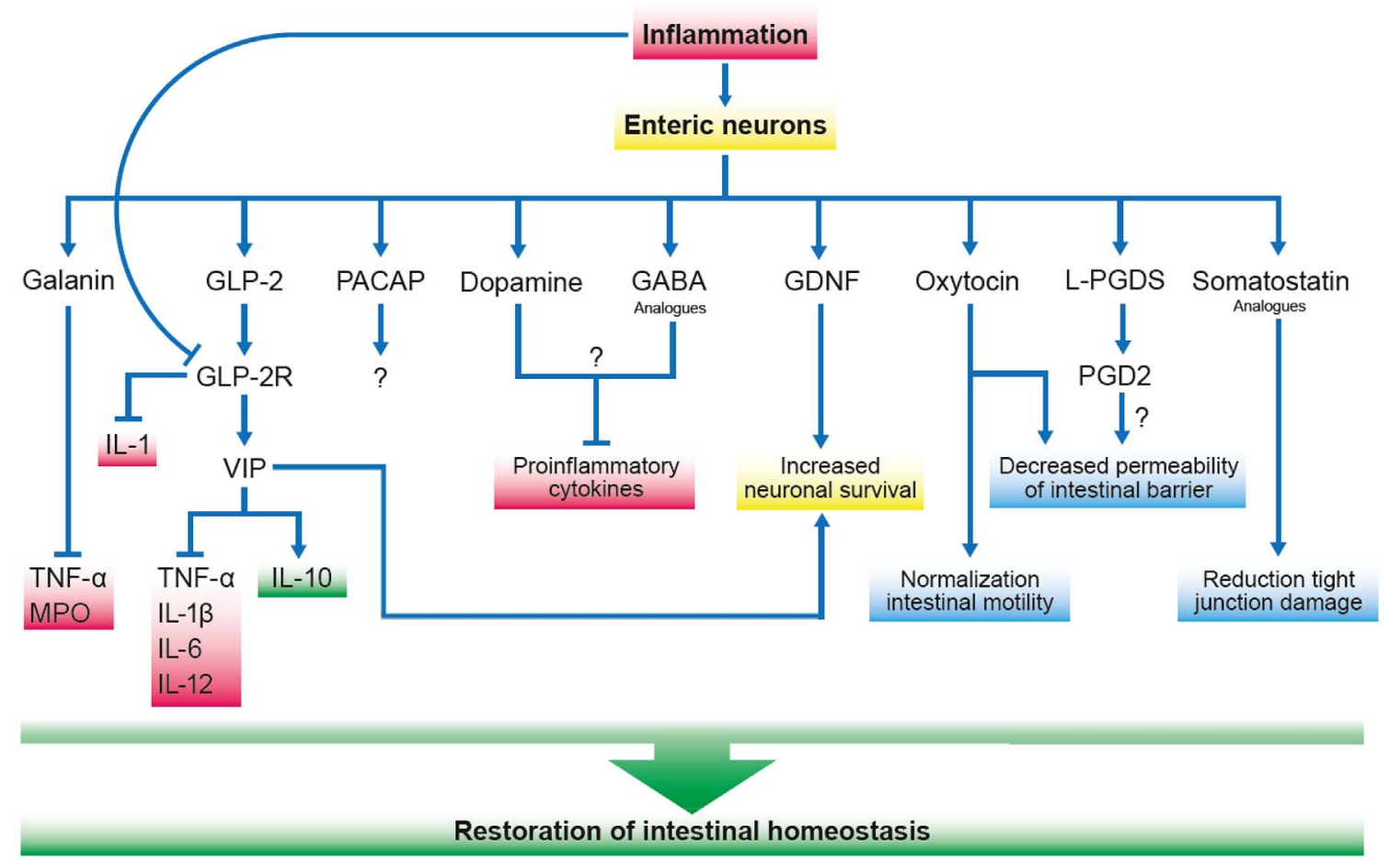

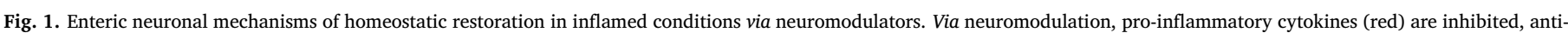

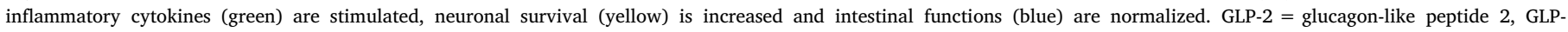

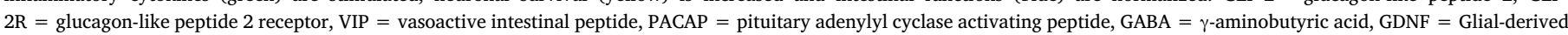

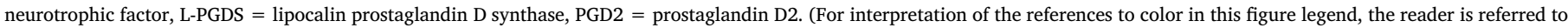
the web version of this article.)

chemically induce colitis. Interestingly, they observed that Hand2 ${ }^{+/-}$ mice, which have a decreased number of neurons, had less severe colitis compared to their wildtype counterparts while NSE-noggin mice, characterized by an increased number of neurons, suffered from more severe colitis, compared to wildtype animals [55].

Many studies describe the impact of different types of neuropeptides, transmitters and hormones on intestinal inflammation. Literature indicates that neuromodulators can be produced and secreted by enteric neurons in response to inflammation and can serve different roles, which can be divided roughly into a homeostasis-restoring function (Fig. 1) and a pro-inflammatory function (Fig. 2). Homeostasis-restoring neuromodulators and hormones as VIP [46,56,57], GLP-2 [58-60], pituitary adenylate cyclase-activating polypeptide (PACAP) [61], galanin [62,63], glial-derived neurotrophic factor (GDNF) [64], oxytocin (OT) [65], prostaglandin D2 (PGD2) [66], somatostatin $[67,68]$, dopamine [69] and GABA [70], inhibit the amount of proinflammatory cytokines, stimulate anti-inflammatory cytokines, decrease intestinal permeability and promote neuronal survival. On the other hand, inflammation-maintaining modulators as neurotensin (NT) [71], substance P [72], 5-HT [41,73], neuropeptide Y (NPY) [74,75] and nerve growth factor (NGF) [76] mainly promote pro-inflammatory cytokines and increase intestinal permeability.

In addition, the interaction of the enteric neurons with immune cells has been studied. Enteric neurons interact with muscularis macrophages, which are located closely to enteric neurons and nerves and can regulate enteric neuronal activity thereby affecting motility and contractility [77]. On the other hand, neurons themselves are involved in the development of macrophages, macrophage homeostasis and polarization. Interestingly, upon enteric bacterial infection, the muscularis macrophages enhanced their tissue-protective programs, which was caused by activation of extrinsic signaling resulting in norepinephrine release followed by binding to the $\beta 2$-adrenergic receptor located on the macrophages. Although the extrinsic signaling is key in this process, the importance of the enteric neurons cannot be ruled out $[77,78]$. The shift in macrophage programming is also recognized in CRC, and specific subsets of macrophages are associated with a specific prognosis although it remains debated whether macrophages exert a pro- or antitumor activity [79]. Thereby it is well established that the ENS is an essential player in the regulation of intestinal inflammation. Overall, these findings between the ENS and inflammation also need to be considered when studying the role of enteric neurons in other intestinal diseases, like CRC.

Intestinal inflammation has also been identified and well-described as an important risk factor for CRC. In most literature, CRC which is associated with intestinal inflammation is referred to as colitis-associated cancer (CAC). This variant of CRC affects approximately $20 \%$ of IBD patients, and almost $50 \%$ of these patients will die $[80,81]$. Although the genetics and the stages of development are highly similar, there are clear differences between CRC and CAC concerning the contribution of inflammatory signaling [82]. First, the activated immune system is able to induce further genetic mutations and epigenetic alterations by the release of reactive oxygen species (ROS) or reactive nitrogen species (RNS) which are known to cause DNA damage [83]. This damage may mutate p53 and mismatch repair genes while cytokines can induce epigenetic alterations or deregulate the expression of miRNAs causing changes in gene silencing [84-87]. Second, inflammatory signals, often released cytokines, are able to induce CRC development via different mechanisms than in non-CAC. The nuclear accumulation of $\beta$-catenin has been found to be regulated via pro-inflammatory factors like tumor necrosis factor alpha (TNF- $\alpha$ ) and prostaglandin $\mathrm{E}_{2}$, or even by pro-inflammatory pathways such as nuclear factor kappa-light-chain-enhancer of activated B cells (NF-kB) or AKT serine/threonine kinase (Akt) [88-90]. Within both sporadic CRC and CAC, the immune system is active. However, in sporadic CRC there is an equilibrium in normal immunosurveillance cells and tumor promoting cells, whereas in CAC more tumor promoting immune cells are detected that can secrete pro-inflammatory cytokines which, together with chemokines, function as growth factors or pro-angiogenic factors for 


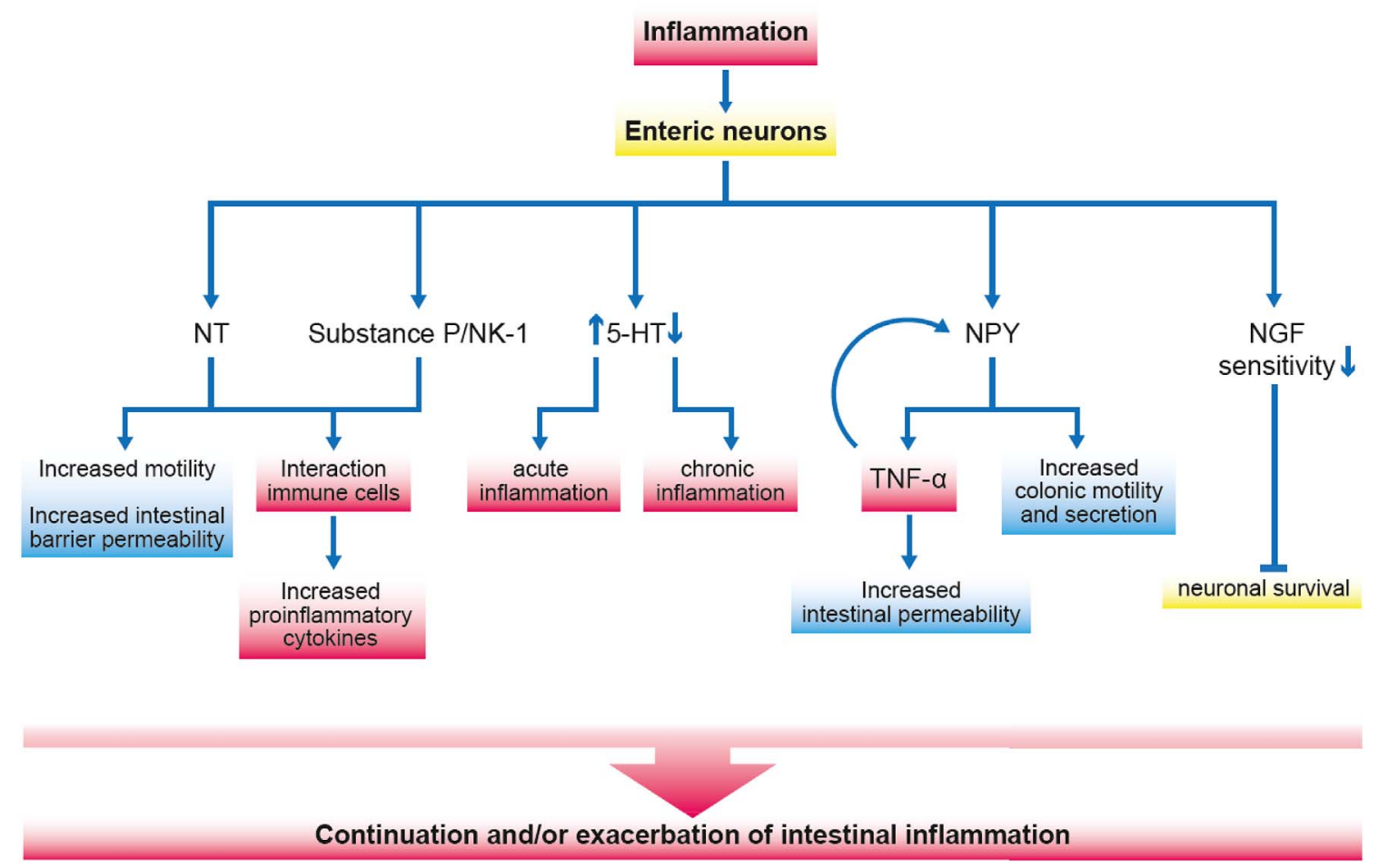

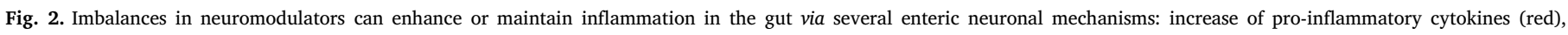

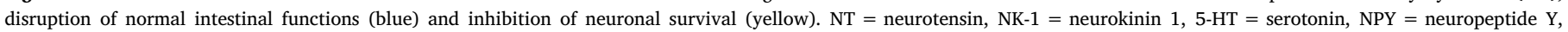
NGF $=$ nerve growth factor. (For interpretation of the references to color in this figure legend, the reader is referred to the web version of this article.)

the tumor [82,91]. Important cytokines for both intestinal inflammation as well as tumor development like TNF- $\alpha$, interleukin (IL)-1 and IL6 are upregulated in IBD and CAC indicating a similar disease-promoting role [92-99]. Finally, the high inflammatory status of the tumor microenvironment also affects processes of invasion and metastasis as pro-inflammatory factors can activate NF- $\mathrm{KB}$ and signal transducer and activator of transcription (STAT) 3 which consequently induce the epithelial-mesenchymal transition and the expression of proteases leading to increased migration and thus invasion/metastasis of tumor cells [100]. For more detailed descriptions on the mechanisms of CAC, we refer the interested reader to the reviews by Terzic et al., Rubin et al., Van der Kraak et al., and Axelrad et al. [82,101-103]. Overall, it can be concluded that there is a strong association between intestinal inflammation and the possibility for the development of CRC/CAC and with the current knowledge on the importance of the ENS in intestinal inflammation, the role of (enteric) innervation in CRC should not be underestimated.

Finally, one should take into account that many studies also describe a decrease of enteric neurons after an inflammatory insult. In dinitrobenzene sulfonic acid (DNBS), TNBS and DSS animal models, the occurrence of inflammation is associated with a significant loss ranging from $20 \%-50 \%$, of enteric neurons [76,104-107]. Additionally, in ulcerative colitis patients the neuronal density in the myenteric plexus was decreased up to $61 \%$ [108]. How these data could be linked to the damaging role of the enteric neurons in the development of gut inflammation, seen by Margolis et al. [55], and CAC/CRC is still unclear. It could be dependent on whether gut inflammation or ENS dysregulation is the primary event. Additionally, it is unknown whether specific subtypes of neurons, and related neurotransmitters and their receptors, are affected.

\section{Innervation in cancer}

It was originally believed that the nervous system only indirectly influences the development/progression of cancer, as tumors spread along nerve fibers in a process called perineural invasion (PNI) [109]. Detection of perineural invasion and related nerve cell markers in tumors is correlated with a poorer disease outcome and/or increased malignancy [25]. This correlation is found in head and neck, prostate, breast, cervical, esophageal, gastric and colorectal cancer [110-121]. For CRC, PNI has been identified as an independent prognostic marker for the outcome and survival in multiple studies [110,121-125]. Burdy et al. was one of the first to investigate the potential prognostic value of PNI in CRC and found that it was associated with high risk of tumor recurrence and decreased survival in T3-T4 node negative CRC patients $[123,124]$. In stage II CRC patients, PNI was significantly associated with the depth of tumor invasion and lymphovascular invasion. More importantly, it was also an independent prognostic factor for diseasefree survival but not overall survival in stage II patients and a strong predictor in stage III patients [122]. Additionally, PNI is correlated with more advanced and aggressive disease $[110,121,126]$. However, Liebl et al. could not validate this independent prognostic potential of neural invasion in CRC despite their observation that increased neural invasion is associated with shorter survival [127]. In 2016, Knijn et al. confirmed the impact of PNI as an independent prognostic factor in 5-year disease free survival (based on 9 studies), 5-year cancer-specific survival (based on 6 studies) and 5-year overall survival (based on 14 studies) in a systematic review and recommended that PNI should be implemented in standard reporting of CRC [125].

Next to this passive role for nerves in carcinogenesis, is the existence of reciprocal interactions between cancer cells and nerves that nowadays has become widely accepted. Cancer cells make use of factors released by nerve fibers to generate a microenvironment positive for cell survival and proliferation. In addition, tumor cells can secrete neurotrophic/neurogenic factors and axon guidance molecules and are therefore able to stimulate their own innervation (via paracrine/autocrine signaling) in a similar way as angiogenesis and lymphangiogenesis [128-131]. This process of the active formation of new nerve fibers and the infiltration into tumors is called neoneurogenesis, and was first described by Entschladen et al. [128,132]. In recent years, 
neoneurogenesis has been identified as an important process in breast and pancreatic cancer, and also in CRC [111,133,134]. Albo et al. were the first to describe the importance of neoneurogenesis in CRC. Using both in vitro and in vivo models, the group observed that there was a higher nerve density in cancerous regions compared to healthy regions. Additionally, high levels of neurogenesis in CRC was described to be an important marker for tumor aggressiveness as 5 -year overall survival is decreased with $50 \%$ in patients with high neurogenesis compared to patients with no/low neurogenesis [111]. These data in combination with the knowledge on the role of perineural invasion clearly depict the essential role of innervation in CRC development and progression.

Recently, a number of landmark papers described the importance of innervation as critical microenvironmental determinants of cancer progression in prostate [25], pancreatic [26], skin [27] and gastric cancers $[28,29]$. Magnon and colleagues demonstrated that prostate tumors are infiltrated by both sympathetic and parasympathetic nerves, originating from normal prostate tissue, indicating that tumors are able to recruit newly developing nerves which are present in the microenvironment. Further investigation regarding the role of the autonomic nerves has shown that sympathetic nerves contribute to cancer development whereas the parasympathetic nerves are able to promote invasion and metastasis [25]. The presence of higher nerve density within the tumor has also been associated with a poorer outcome, indicating the potential role of nerve fiber density as a prognostic marker for prostate cancer [25]. Zhao et al. and Hayakawa et al. show a similar role for nerve fibers in gastric cancer. Regions of the stomach with higher vagal innervation have an increased chance of tumor development and when these areas are denervated, the number of tumors and progression of the cancer is attenuated [28]. Zhao et al. described that neurons co-cultured with gastric organoids showed neurite outgrowth and this resulted in enhanced gastric organoid growth, working through cholinergic induced Wnt signaling [28]. This was further studied by Hayakawa et al. who showed that the release of ACh from nerves, as well as tuft cells (a specialized epithelial cell involved in immune regulation and "tasting" luminal content), which are intermediary cells dependent on innervation [135], stimulates epithelial cells to release NGF thereby increasing enteric neurons (HuC/D immunoreactive cells) and neurite outgrowth causing a positive feedback loop [29,136]. Via this loop, ACh can promote epithelial proliferation via muscarinic signaling and subsequently yes-associated protein (YAP)-Wnt signaling hereby promoting tumor growth, particularly after loss of adenomatous polyposis coli [29]. In addition to prostate and gastric cancer, tumor development and progression in pancreatic ductal adenocarcinoma (PDAC), is also accompanied by several neuroplastic changes. PDAC is associated with hypertrophy of the nerve bundles, and an increase in sensory innervation and pancreatic neurotrophic factor mRNA expression [26]. Finally, it is well-established that the Hedgehog pathway is an important hallmark of basal cell carcinoma. However, Peterson et al. recently observed that only specific innervated stem cell populations, located within the mechanosensory touch dome epithelia, show activated Hedgehog signaling and are highly tumorigenic upon loss of Patched1. Moreover, they observed that surgical denervation decreases touch dome derived tumors, emphasizing the importance of cutaneous sensory nerves in the development of skin cancer [27].

These studies indicate that innervation in the periphery can affect different processes in the development of cancer and have shown and/ or discussed the importance of nerve-derived release of neurotransmitters like ACh and growth factors like NGF as key factors to promote cancer development. Overall, these papers set the stage to further investigate the potential role of the ENS in the development and progression of CRC.

\section{Enteric nervous system and colorectal cancer}

In addition to the hallmark papers described above that highlight the importance of peripheral neurons in carcinogenesis, several papers provide preliminary evidence consistent with a link between the ENS and CRC development/progression. We recently described that N-mycdownstream-regulated-gene 4 (NDRG4), an established biomarker for the early detection of CRC, is specifically expressed in the ENS [137-139]. It has been described that NDRG4 has a role in vesicular transport in cells, because of its interaction with blood vessel epicardial substance, which has been shown to regulate docking of vesicle associated membrane protein 3 (VAMP-3, a SNARE-protein) positive vesicles to the cell surface and the subsequent cargo delivery (e.g. fibronectin) [140]. Moreover, NDRG4 controls vesicle membrane fusion during exocytosis as NDRG4 knockdown has been associated with a sharp reduction in the level of another vesicle-SNARE protein, Synaptosomal-associated protein 25 (SNAP25) [141]. Although the exact function of NDRG4 in the gut still has to be investigated, we hypothesize that NDRG4 is able to modulate subcellular vesicle trafficking and exocytotic release of neurotransmitters. Another interesting observation linking the ENS and CRC is that patients with megacolon which have decreased innervation of the intestine (a symptom associated with Chagas disease), have reduced risks for developing CRC. Garcia et al. tested 802 patients with megacolon and identified that none of these patients presented CRC and only three patients were found with intestinal polyps [142]. The same outcome was observed by Vespúcio et al. who described that Wistar rats with a reduced number of myenteric neurons had diminished preneoplastic markers, like aberrant crypt foci, crypt fission index, $\beta$-catenin accumulated crypts, and epithelial cell proliferation, after treatment with a carcinogenic drug, compared to rats with normal numbers of myenteric neurons [143]. Other evidence for an association between the ENS and CRC can be found within the netrin-1 signaling pathway [144]. Netrin-1 is a protein which is involved in axonal guidance in both the CNS and the ENS, and its receptor DCC (Deleted in Colorectal Cancer) was found to be expressed in the developing ENS $[145,146]$. DCC induces apoptosis, unless it is affianced by its ligand, netrin-1, and its expression is often reduced in CRC [147-149]. Because of the important role of netrin-1 and its receptor in both ENS and CRC, Ko et al. also debated that the ENS could be an important contributor to CRC development [144].

In addition to the innervation promoting tumor development and progression, CRC-induced alterations within the ENS have also been described. Godlewski et al. [150] described that a tumor is able to displace the myenteric and submucosal plexuses often with loss of nerve fibers and neurons. If the invasion pattern of the tumor is more dispersed, the tumor can surround the submucosal layer thereby destroying it. Due to the loss of innervation, markedly altered gut functions could occur, causing symptoms such as alterations in bowel movements, constipation, diarrhea and pain [150]. Other studies investigated the increase or decrease of specific neurotransmitter-expressing neurons and nerve fibers within the ENS in the region adjacent to the cancer invaded area in the intestines of patients with CRC [151-153]. A decrease of NPY and CGRP, substance P, somatostatin and PACAP-expressing neurons is observed within the submucosal plexus and a decrease of CGRP, NPY and in a lesser extent somatostatinexpressing neurons is observed in the myenteric plexus. Only galaninexpressing neurons were increased in the myenteric plexus in CRC. No changes were observed for VIP in both myenteric and submucosal plexus [151-153]. However, rats with chemically induced colonic adenocarcinoma showed an increased number of substance P and VIP immunoreactive nerve fibers while nitric oxide synthase (NOS) immunoreactive nerve fibers were decreased [154]. Together these data indicate that the neurochemical coding of neurons and nerve fibers in CRC conditions are significantly different compared to a healthy situation.

\section{Neuromodulators and their role in CRC development/ progression}

As described above, neuromodulators have major influences on gut 
function. Current research is predominantly focused to identify which neurotransmitters and neurotrophic factors are involved in cancer development as there is increasing evidence that these factors can affect migration, invasion and metastasis [155]. Tumor cells express different neurotransmitter receptors and react with different neurotransmitters [156]. In addition, tumor cells can produce endogenous neurotransmitters in response to several environmental stimuli [156].

The first neurotransmitter that was associated with CRC was VIP. As early as the 1970's it was demonstrated that VIP receptors were present in the malignant colonic cell line HT-29. Alleaume et al. showed that the addition of VIP increases proliferation of HT29 cells [157] and this was confirmed in the in vivo study of Iishi et al., who studied the effects of VIP on colonic tumors in azoxymethane (AOM)-treated Wistar rats [158]. Regular injections with VIP in this rat model of CRC led to a higher incidence of colonic tumors [158]. When using a VIP antagonist in AOM-treated Sprague Dawley rats, the volume, staging, number of dysplastic crypts, and lymphocyte infiltrate in the tumors was reduced [159]. One proposed mechanism of how VIP could influence these effects is via the production and accumulation of cyclic adenosine monophosphate (CAMP) and the activation of extracellular signalregulated kinases (ERK), which can both lead to enhanced proliferation [157]. However, opposite results have been shown by Ogasawara et al., who studied the effect of VIP on invasion and migration of murine colon 26-L5 adenocarcinoma cells and concluded that VIP is able to inhibit migratory/invasive processes of 26-L5 adenocarcinoma cells [160]. Moreover, it has been described that treatment with VIP and the VIP analogue PACAP, reduces cell growth in HCT116, SW403, DLD-1 and Caco-2 cell lines, but also in HT29 cells [161,162]. How VIP exerts these different effects remains to be determined. However, as observed for other neurotransmitters, e.g. PACAP, it might be reliant on the activated receptor. PACAP has been associated with a diversity of functions, for example the regulation of cell division, cell differentiation and apoptotic cell death in neuronal and some non-neuronal cell types [163]. Interestingly, PACAP can both stimulate and inhibit proliferation of one cell type which is dependent on the distribution of the PACAP receptors: $\mathrm{PAC}_{1}-\mathrm{R}$-s or $\mathrm{PAC}_{1}$-R-hop. $\mathrm{PAC}_{1}-\mathrm{R}$-s is able to stimulate proliferation, whereas $\mathrm{PAC}_{1}-\mathrm{R}$-hop functions via another signaling pathway to inhibit proliferation [164]. Interestingly, in an in vivo study, it was observed that DSS-treated PACAP ${ }^{-/-}$mice spontaneously developed aggressive colorectal tumors, while control mice only displayed minor neoplastic changes [61]. In addition, tumors of the $P A C A P^{-/-}$mice also had a more aggressive-appearing pathology compared to the tumors of control mice [61]. Together, these data suggest that PACAP has a tumor suppressor role in CRC, although the underlying mechanisms are still unknown. Following the discovery that VIP and its analogue PACAP are able to affect cancer development, various groups started to investigate the possible role of neuropeptides/transmitters in cancer. An increasing number of studies have now investigated the role of different neuromodulators in the development and progression of CRC, which we will summarize below.

The substance $\mathrm{P} /$ neurokinin 1 receptor complex is involved in mitogenesis, angiogenesis, cell migration and metastasis [165]. Substance P can bind to all members of the neurokinin receptor family although its binding with the neurokinin-1 (NK-1) receptor has been most fully investigated. The NK-1 receptor was identified in colon adenocarcinomas by Rosso et al., who reported that low concentrations of substance $P$ are able to increase growth of SW-403 cells and that blocking the receptor using an NK-1 antagonist could inhibit growth and induce cell death via apoptosis [166]. These results were confirmed by inhibiting substance P using anti-substance P antibodies in HT29 and HCT116 cancer cells [167]. Garnier et al. described that by using NK-1 receptor antagonists in DLD1 cell lines, the canonical Wnt signaling was inhibited giving an insight into the mechanism of substance P/NK-1 signaling in cancer [168]. Thus, substance P has been found to play a stimulating role in the development of CRC. Because substance $\mathrm{P}$ can promote tumor growth in other types of tumor besides CRC as neuroblastomas, gliomas, retinoblastoma, melanomas, pancreatic carcinomas and gastric carcinomas, the possibility of using NK-1 receptor antagonists as a therapeutic has led to the development of several different antagonists [169]. Despite their structural differences, Aprepitant, benzylether piperidine (L-733,060) and $N$-acetyl-L-tryptophan-3,5-bis(trifluoromethyl)benzyl-ester (L-732,138) bind the NK-1 receptor with a similar specificity thereby inhibiting tumor growth $[170,171]$. Besides the direct antitumoral effect of the NK-1 receptor antagonists, Alfieri et al. have shown that the use of these antagonists reduced side effects caused by chemotherapy and/or radiotherapy [172]. However, aprepitant has also been found to induce CYP3A4 and when aprepitant is co-administered with drugs metabolized by CYP3A4, it could lead to increased plasma levels. Therefore the usage of aprepitant in combination with chemotherapeutic agents metabolized by CPY3A4 should be investigated thoroughly as this combination could potentially result in altered drug efficacy or toxicity due to the interactions between aprepitant and the chemotherapeutic agent [173]. Therefore, more research of NK-1 receptor antagonists in CRC is needed to optimize their potential as broad-spectrum antitumor drugs.

Serotonin, a biogenic amine found in nerves and enterochromaffin cells throughout the GI tract is another neurotransmitter that has been studied in the context of CRC development. In vivo and in vitro studies suggest an inhibitory effect of 5-HT on CRC. Tutton et al. showed that treatment with 5-HT reuptake inhibitors (Citalopram and Fluoxetine) has a suppressive effect on proliferation in dimethylhydrazine-induced colonic tumors in rats and mice with xenografted carcinomas [174]. Following this study, $\mathrm{Xu}$ et al. discovered that the daily use of 5-HT reuptake inhibitors (commonly used antidepressants) is associated with a reduced risk for developing CRC in a population based nested casecontrol study [175]. These findings have been supported by several other studies [176-178], although a Danish population-based study described no association between 5-HT reuptake inhibitor use and CRC risk [178]. In contrast, other studies revealed stimulating effects of 5HT on CRC, when using an 5-HT receptor antagonist. In a study by Barkla et al., the effects of 5-HT were prevented by treating xenografted carcinomas in mice with a 5-HT receptor antagonist (BW 501c), which resulted in decreased tumor growth [179]. In order to get a better understanding of the impact of 5-HT on CRC, Ataee et al. conducted several studies investigating the involvement of the 5-HT receptors and described that $5-\mathrm{HT}_{1 \mathrm{~B}}, 5-\mathrm{HT}_{3}$ and $5-\mathrm{HT}_{4}$ are expressed in $\mathrm{HT} 29$ cells and that binding of $5-\mathrm{HT}$ with all three receptors stimulates cell proliferation and that 5-HT antagonists inhibited cancer cell growth [180,181]. The activation of different intracellular signaling cascades triggered by the different 5-HT receptors could explain the diverse effects of 5-HT [182].

Neuropeptide $Y$ plays an important role in the regulation of immune cells, gastrointestinal motility and intestinal secretion during healthy conditions [74]. It has been described that NPY and its Y2 receptor are upregulated in mouse models of CRC (treated with the carcinogen AOM and the inflammatory agent DSS). Further in vitro data showed that NPY can promote the angiogenic potential through Y2 receptors and thus may act as an important factor in the development of CRC [183]. The calcium binding protein, calretinin is mainly present in secretomotor/ vasodilator neurons which innervate the secretory glands and which also regulate the blood flow through arterioles [42]. Calretinin is expressed in 10 different colorectal cell lines, generally known as cells with a high proliferation rate.: i.e. HT-29, WiDr, LoVo, LS180, CO112, CO115, SW480, SW620, COLO205 and SK-CO-1, In contrast, SW1116 and Caco-2, slow proliferating cells, do not express calretinin indicating a role for calretinin in proliferation [184]. Expression of calretinin has also been studied in a series of human colorectal adenocarcinomas where the expression levels increased with tumor progression, being associated with increased malignancy and metastasis, while calretinin expression is lacking in normal multiplying cells $[185,186]$.

Two other enteric neurotransmitters that have been studied in CRC are GABA and the catecholamine dopamine. GABA acting at $\mathrm{GABA}_{\mathrm{B}}$ receptors can inhibit metastasis of $C R C$ in mice injected with the KM12SM, HT29 or RKO cell lines, and migration of SW480 cells 
$[187,188]$. In contrast, increased levels of GABA have been observed within human tumors. Thus its exact role remains unclear [187,188]. Dopamine, a catecholamine within the autonomic and enteric nervous system, has been associated with the inhibition of cancer growth. By stimulating dopamine receptors, an inhibitory effect on CRC growth is observed induced via an antiangiogenic action of dopamine [189].

The catecholamines, epinephrine and norepinephrine originate from the central nervous system (CNS). The CNS and the ENS are able to communicate and therefore the CNS can modulate the ENS which is important for the brain-gut axis [3]. Epinephrine and norepinephrine can reduce the release of neurotransmitters like 5-HT and substance P [42]. Both epinephrine and norepinephrine have been found to stimulate the migratory activity of SW480 cells [190]. Additionally, (nor) epinephrine, which activates $\beta$-adrenergic receptors, has also been found to promote metastasis in CRC [190]. It has been described that these catecholamines can be stimulated via acetylcholine (receptors) in colon cancer [191]. Next to stimulating catecholamines, stimulation of the ACh receptors was shown to primarily promote tumor development. This was achieved by stimulating the nicotinic as well as the muscarinic receptors with a variety of agonists. The activation of nicotinic ACh receptors by nicotine led to increased cell proliferation in HT29, Caco-2 and HCT- 8 cells and decreased apoptosis in the Caco- 2 and HCT-8 cells $[191,192]$. On the other hand, the muscarinic ACh receptors that were stimulated with ACh had a stimulatory effect on cancer cell migration and invasion in H508 and HT29 cells [193,194].

In addition to neurotransmitters, some enteroendocrine peptides have been studied during colorectal carcinogenesis. Glucagon-like peptide 2, found in L cells in the intestinal epithelium has been identified as a potential mediator of intestinal epithelial proliferation [195]. Due to these proliferative properties, Thulesen et al. studied the effect of GLP-2 on cancer development in 1,2-dimethylhydrazine (a carcinogen) treated mice, where the additional treatment with GLP-2 increased the tumor load indicating a pro-cancerous role of GLP-2 [196]. This cancer-promoting potential was confirmed in several models, including in an AOM-induced CRC rodent model where treatment with GLP-2 led to increased high-grade dysplasia and treatment with a GLP-2 antagonist decreased dysplasia [197]. Therefore GLP-2 is considered as a potential target for anti-cancer therapy [198]. Neurotensin, another enteroendocrine peptide, also stimulates the growth of CRC as shown in different colon cancer cell lines (SW480, SW620, HT29, HCT116, LoVo, and MC-26) and in tumors xenografted into nude mice [199-201]. However, later studies showed that neurotensin receptor- 1 is specifically involved in promoting tumor development in sporadic cancers (AOM-model) but not in CAC (AOM/DSS) [202]. In 2011, it was discovered that neurotensin signaling activates microRNA 21 and 155 which subsequently activated Akt thereby promoting tumor growth in HCT116-xenograft tumors. Blocking of the microRNAs slowed tumor growth [203].

Currently, the role of enteroendocrine peptides, as an alternative/ additional treatment for chemotherapy and radiotherapy in cancer, is under investigation. While hormonal manipulation in breast and prostate cancer is well established, it is barely used as a treatment option for CRC patients. In 1989 it was investigated that CRC patients could benefit from hormonal therapy with antigastrin drugs [204]. Hormones like gastrin have been shown to play a role in cancers of the GI tract [205]. Ciccotosto et al. observed that gastrin levels are significantly elevated in CRC patients compared to a control group [206]. Gastrin is able to exert trophic effects via endocrine, autocrine and paracrine pathways as shown in studies using CRC lines (HT29, HCT116) and colorectal xenografts in nude mice [207-210]. Somatostatin, one of the most widely distributed gut hormones, is known to have an inhibitory effect on gastric acid secretion, intestinal absorption and motility [211]. The first studies concerning somatostatin originate from the 1980s where contradictory results were described regarding the effect of different somatostatin-analogues in CRC. One of the earliest and best studied analogues for somatostatin, in the context of CRC, is octreotide.
In an early study, no inhibitory effect on tumor growth was observed after the treatment with this somatostatin-analogue in a AOM-induced CRC rat model [212]. However, in later studies, it was described that octreotide could inhibit tumor growth in vitro and in vivo using xenograft mice models [213]. Similarly, another analogue for somatostatin, AN-162, was also able to inhibit tumor growth as found in HT-29, HCT15 and HCT-116 cell lines [214]. Mono-treatment with octreotide in SW620 cells led to a reduction of viable cells, but when octreotide was used in combination with 5-HT and galanin, the effects were enhanced [215]. The positive outcome of this combination treatment was confirmed in vivo in C578L/6jBom-nu nude mice injected with cells of an $N$ methyl- $N$-nitroguanidine-induced rat colon carcinoma, by the decreased tumor volume due to increased apoptosis and necrosis, and reduction of blood vessel density [215-218]. Evidence for a role of galanin in CRC development was described in the 1990's by Iishi et al., who showed that galanin treatment leads to a decreased incidence of colonic tumors in Wistar rats during a limited follow-up period [219]. It was not until 2007, that Kim et al. observed with microarray analysis that galanin expression is increased in colon cancer tissue (51 colon adenocarcinomas) compared to normal tissue (15 normal colons) [220]. In addition, it has been described that galanin-positive neurons are increased in the myenteric plexus of diseased regions affected by CRC compared to non-diseased areas [220]. Moreover, Nagayoshi et al. discovered that galanin is important in cancer invasiveness and that high expression of galanin is associated with a more aggressive form of CRC with a poorer prognosis for stage II patients [221]. Although further studies are necessary, it is suggested that galanin signaling may act as prognostic and potentially therapeutic target for stage II patients specifically.

Finally, besides the release of neurotransmitters and hormones, the importance of specific receptors found within the ENS should also be considered. Receptors that are important in calcium influx, calciumdependent processes and are involved in purinergic signaling as part of the neuron-to-glial cell communication within the ENS, are the P2X receptors [222,223]. Overall, it has been accepted that purinergic signaling functions via P2X purinoceptor 7 (P2X7R) is involved in the maintenance of gut homeostasis by regulating both motor and secretory functions [224-226]. Gulbransen et al. have described an essential role of P2X7R in the development of IBD, as described above, but more recently Hofman et al. have also shown that P2X7R is involved in the development of CAC [227]. Whereas P2X7R inhibitors can reduce neuronal cell death and hereby the development of IBD [107], this study also showed that blockage of P2X7R can enhance proliferation of intestinal epithelial cells and reduce apoptosis, which increases the risk of CAC $[107,227]$.

Overall, studies investigating the role of neuromodulators and specific receptors in cancer have shown that CRC development and progression can be modulated by neural invasion and a variety of enteric transmitters. We have summarized the effect of the above described neuromodulators on different hallmarks of cancer in Table 1. Neurons producing factors like somatostatin, PACAP, dopamine and GABA will be able to inhibit the progression of cancer while substance $P$, galanin, NPY, epinephrine, norepinephrine, and ACh are able to promote proliferation, growth, migration, invasion and angiogenesis, as summarized in Fig. 3. Many neurotransmitters that have been found to stimulate CRC, have also been studied in the context of gut inflammation, as described in Figs. 1 and 2. It is interesting to see that NPY and substance $\mathrm{P}$, for example, promote CRC and inflammation, and that PACAP has a protective effect on both inflammation and CRC. As the link between inflammation and CRC development is well established, one might assume that neuromodulators have the same positive or negative effects on cancer and inflammation in the intestines [82]. The neuromodulators discussed in this review have been mostly studied by their exogenous administration to cells or by administering them as a treatment, but all of these neuromodulators are also endogenously present in the ENS. Whether these can be harnessed to prevent the development or 


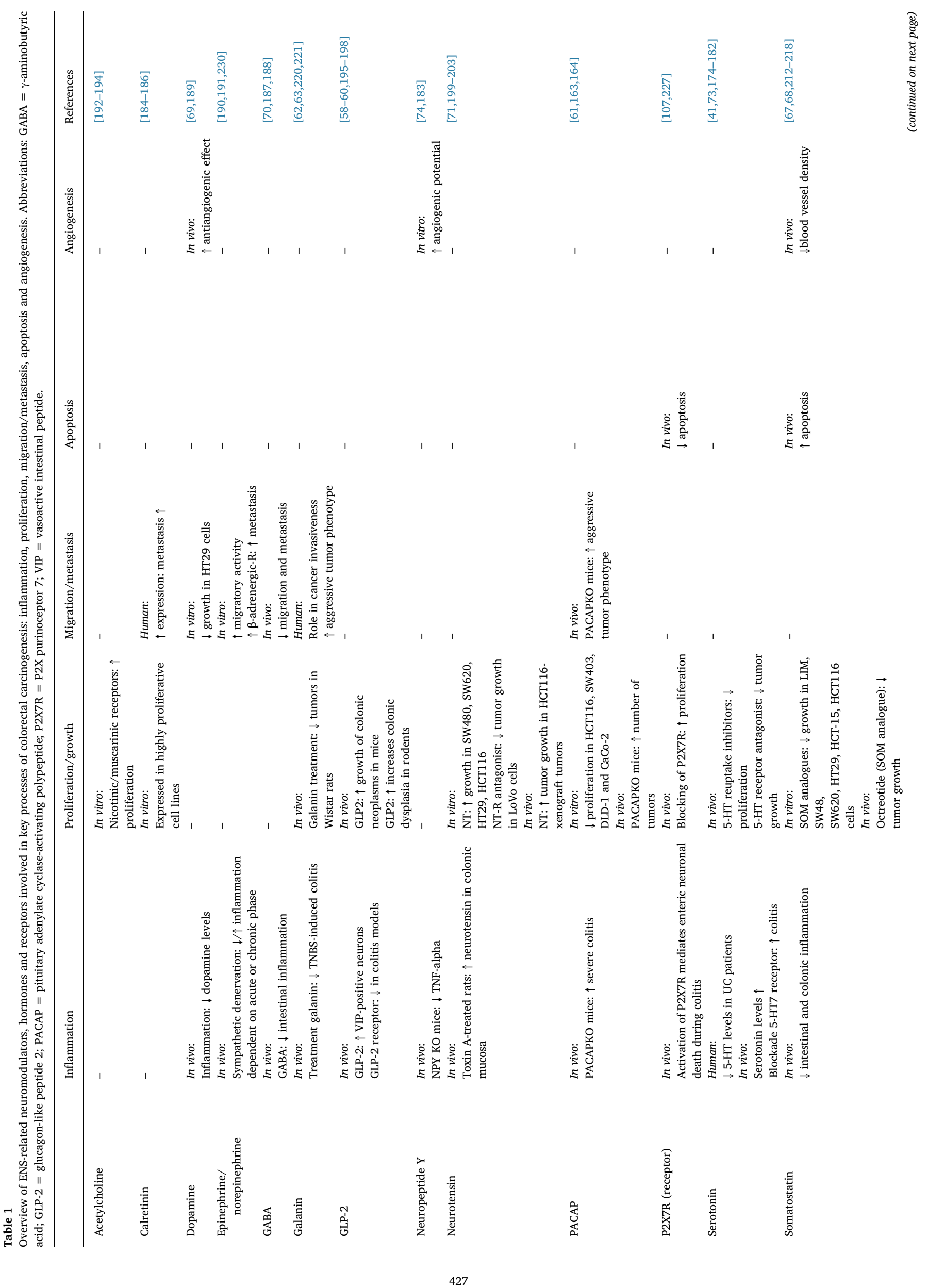


progression of CRC remains to be determined. Most of these neurotransmitters are produced and released in both the autonomic and enteric nervous systems and might thus affect CRC development or progression, however, as described, little knowledge is available about the exact contribution of the ENS in CRC. Nonetheless, the ability of the neuromodulators to affect cancer development and progression could be of significant value for future therapeutic targets.

\section{Targeting innervation in cancer - therapeutic potential}

In general, both PNI as well as the presence of neurogenesis have been associated with poorer prognosis and decreased survival in CRC $[110,111,121-125,127]$. Because of the good prognostic potential of PNI and neurogenesis in CRC, these factors could play an important role in therapy stratification (use of adjuvant therapy or postoperative chemotherapy) $[110,111,122]$. Magnon et al. and Zhao et al., suggested that denervation of tumors can act as a potential therapy to treat prostate and gastric cancer, respectively, as they showed that surgical denervation using vagotomy or removal of hypogastric nerves, as well as pharmacological denervation using unilateral injections with botulinum toxin A, lead to attenuation of cancer development and progression $[25,28]$. The same effect was observed in pancreatic cancer, where patients whose innervation was ablated had a slightly better survival rate $[26,228,229]$. Recently, Jobling et al. reviewed strategies targeting the neurotrophic factor NGF, also considered by Hayakawa et al. as a potential target [29]. NGF stimulates nerve infiltration but also cancer cell proliferation and invasion in breast, prostate and gastric cancer. Using antineurogenic therapies, nerve infiltration can be inhibited and by decreasing the release of tumor-stimulating neurotrophic growth factors, processes as proliferation and migration can also be inhibited [218]. Although NGF has not been associated with CRC, the principle of targeting innervation and related neurotrophic factors and their receptors to battle cancer is also supported by previously mentioned hallmark papers $[25,26,28,29]$.

\section{Conclusions \& discussion}

Enteric neurons play an essential role in controlling normal GI function by regulating intestinal homeostasis via alterations in permeability, motility, blood flow and fluid exchange/secretion. An important role of enteric neurons in intestinal inflammatory conditions and genetic diseases like Hirschsprung's disease has been identified over the years. In intestinal inflammatory conditions, both homeostasis-restoring and inflammation-maintaining neuromodulation have been described. While the important role of the ENS is unequivocal, and it is well-known that gut inflammation often precedes CRC development, studies investigating the direct influence of the ENS in the development and/or progression of CRC are lacking. However, as we have described in this review, there is an enormous potential for the ENS to impact CRC carcinogenesis directly, and indirectly through the regulation of inflammation in the gut.

Evidence clearly indicates that tumors with high innervation, due to neoneurogenesis and perineural invasion, are more aggressive and malignant and are associated with poorer survival which can be improved by denervation of the tumors. Moreover, studies focusing on the ENS and CRC showed that patients or animals with compromised enteric innervation have decreased risk for CRC development. Other evidence clearly indicates that neuromodulators released from the ENS affect different processes of cancer development and progression.

Overall, we believe that the ENS should be considered as an important player in the development/progression of CRC, although more research is necessary to understand the exact mechanisms of neuronalepithelial communication. As illustrated in Fig. 4, we hypothesize that enteric neurons communicate with the epithelial cells in two ways. Firstly, we believe that epithelial cells/tumor cells will receive direct input by neuromodulators originating from the innervation. Secondly, 


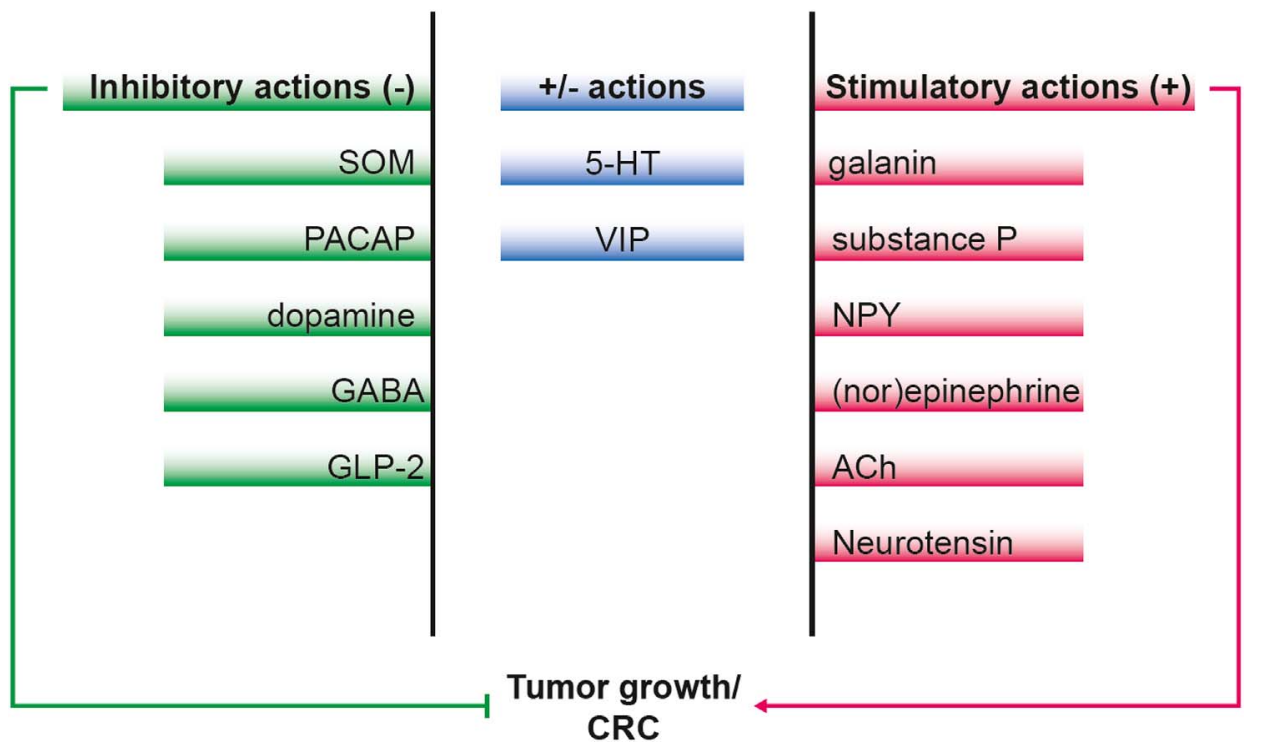

Fig. 3. Proposed effects, either inhibitory (green), stimulatory (red), or dual (inhibitory and stimulatory, blue) on the development of CRC by neuromodulators. $\mathrm{SOM}=$ somatostatin, PACAP $=$ pituitary adenylyl cyclase-activating peptide, $\mathrm{GABA}=\gamma$-aminobutyric acid, GLP-2 = glucagon-peptide 2, NPY = neuropeptide Y, $\mathrm{ACh}=$ acetylcholine. (For interpretation of the references to color in this figure legend, the reader is referred to the web version of this article.)
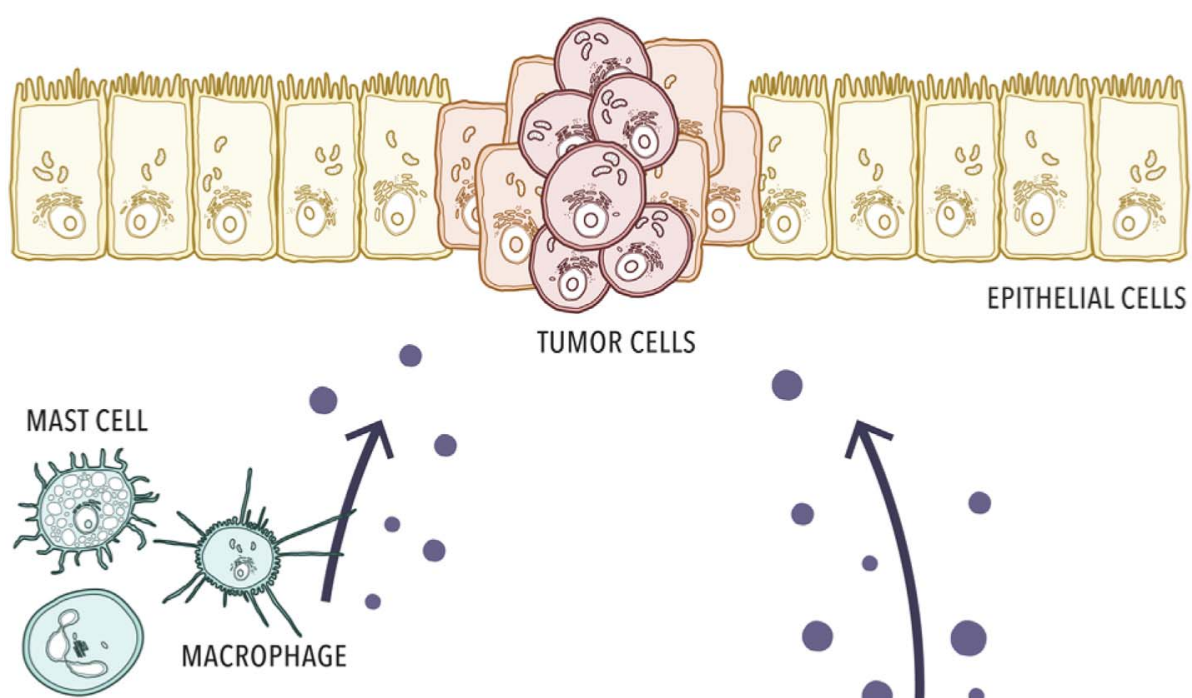

NEUTROPHIL
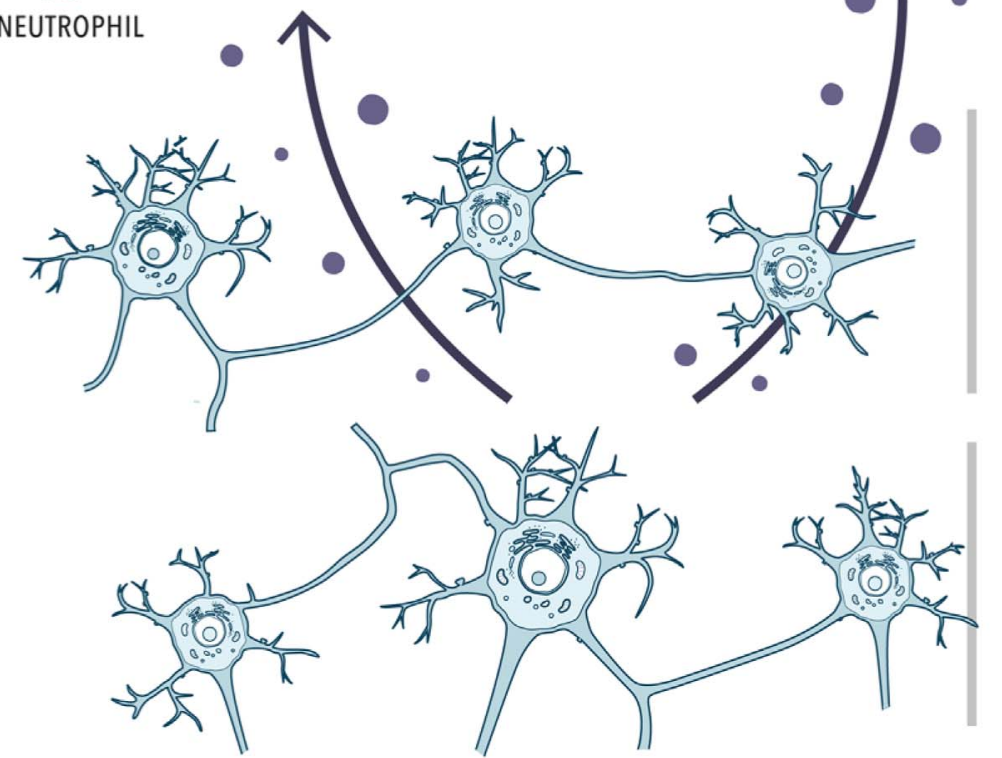

ENTERIC NEURONS
SUBMUCOSAL PLEXUS

MYENTERIC PLEXUS
Fig. 4. Enteric neurons located in the submucosal and myenteric plexus can target epithelial and/or tumor cells via the release of neuromodulators to initiate or prevent the development of cancer. This can be either directly (right arrow) or indirectly via immune cells (left arrow). Via this mechanism, processes involved in cancer development or progression are either stimulated or inhibited, depending on the balance of enteric neuromodulation. 
we hypothesize that neurons indirectly communicate with epithelial cells via immune cells.

In conclusion, initial evidence accumulated in this review, suggests that enteric neurons have the potential to be important players in the development and/or progression of CRC, by either direct or indirect targeting epithelial cells/function.

\section{Transparency document}

The http://dx.doi.org/10.1016/j.bbcan.2017.08.003 associated with this article can be found, in online version.

\section{Acknowledgements}

This work was supported by a grant from KWF Kankerbestrijding (UM-2013-6075) and the Foundation 'De Drie Lichten' (47/15) in The Netherlands. KAS is the Crohn's and Colitis Canada Chair in IBD Research at the University of Calgary.

Thanks to Tom de Vries Lentsch (Erasmus Medical Center, Rotterdam) for help with the figures/illustrations.

\section{Disclosure of potential conflicts of interests}

No potential conflicts of interest were disclosed by the authors.

\section{References}

[1] J.B. Furness, The enteric nervous system and neurogastroenterology, Nat. Rev. Gastroenterol. Hepatol. 9 (2012) 286-294.

[2] M. Rao, M.D. Gershon, The bowel and beyond: the enteric nervous system in neurological disorders, Nat. Rev. Gastroenterol. Hepatol. 13 (2016) 517-528.

[3] J.D. Wood, D.H. Alpers, P.L. Andrews, Fundamentals of neurogastroenterology, Gut 45 (Suppl. 2) (1999) II6-II16.

[4] M.D. Gershon, The enteric nervous system: a second brain, Hosp. Pract. 34 (1999) (1995) 31-32 (35-38, 41-32 passim).

[5] F. Obermayr, R. Hotta, H. Enomoto, H.M. Young, Development and developmental disorders of the enteric nervous system, Nat. Rev. Gastroenterol. Hepatol. 10 (2013) 43-57.

[6] M.B. Hansen, The enteric nervous system I: organisation and classification, Pharmacol. Toxicol. 92 (2003) 105-113.

[7] T. Wedel, U. Roblick, J. Gleiss, T. Schiedeck, H.P. Bruch, W. Kuhnel, H.J. Krammer, Organization of the enteric nervous system in the human colon demonstrated by wholemount immunohistochemistry with special reference to the submucous plexus, Ann. Anat. 181 (1999) 327-337.

[8] J.P. Timmermans, D. Adriaensen, W. Cornelissen, D.W. Scheuermann, Structura organization and neuropeptide distribution in the mammalian enteric nervous system, with special attention to those components involved in mucosal reflexes, Comp. Biochem. Physiol. A Physiol. 118 (1997) 331-340.

[9] J.D. Wood, Chapter 21 - cellular neurophysiology of enteric neurons, in: L.R.J.K.G.D.K.L.M.M.S.D. Wood (Ed.), Physiology of the Gastrointestinal Tract, Fifth ed., Academic Press, Place Published, 2012, pp. 629-669.

[10] M.D. Gershon, The enteric nervous system, Annu. Rev. Neurosci. 4 (1981) 227-272.

[11] W.F. Boron, E.L. Boulpaep, Medical Physiology: A Cellular and Molecula Approach, Saunders/Elsevier, Place Published, 2009.

[12] M. Neunlist, L. Van Landeghem, M.M. Mahe, P. Derkinderen, S.B. des Varannes, M. Rolli-Derkinderen, The digestive neuronal-glial-epithelial unit: a new actor in gut health and disease, Nat. Rev. Gastroenterol. Hepatol. 10 (2013) 90-100.

[13] M.B. Hansen, The enteric nervous system II: gastrointestinal functions, Pharmacol. Toxicol. 92 (2003) 249-257.

[14] A. Pini Prato, V. Rossi, S. Avanzini, G. Mattioli, N. Disma, V. Jasonni, Hirschsprung's disease: what about mortality? Pediatr. Surg. Int. 27 (2011) $473-478$.

[15] J. Ferlay, I. Soerjomataram, R. Dikshit, S. Eser, C. Mathers, M. Rebelo, D.M. Parkin, D. Forman, F. Bray, Cancer incidence and mortality worldwide: sources, methods and major patterns in GLOBOCAN 2012, Int. J. Cancer 136 (2015) E359-386.

[16] M.M. Center, A. Jemal, R.A. Smith, E. Ward, Worldwide variations in colorecta cancer, CA Cancer J. Clin. 59 (2009) 366-378.

[17] A. Jemal, M.M. Center, C. DeSantis, E.M. Ward, Global patterns of cancer incidence and mortality rates and trends, Cancer Epidemiol. Biomark. Prev. 19 (2010) 1893-1907.

[18] E.R. Fearon, B. Vogelstein, A genetic model for colorectal tumorigenesis, Cell 61 (1990) $759-767$.

[19] M. van Engeland, S. Derks, K.M. Smits, G.A. Meijer, J.G. Herman, Colorectal cancer epigenetics: complex simplicity, J. Clin. Oncol. Off. J. Am. Soc. Clin. Oncol. 29 (2011) 1382-1391.
[20] G. Lorusso, C. Ruegg, The tumor microenvironment and its contribution to tumor evolution toward metastasis, Histochem. Cell Biol. 130 (2008) 1091-1103.

[21] L.M. Coussens, Z. Werb, Inflammation and cancer, Nature 420 (2002) 860-867.

[22] S.C. Robinson, L.M. Coussens, Soluble mediators of inflammation during tumor development, Adv. Cancer Res. 93 (2005) 159-187.

[23] R. Benelli, G. Lorusso, A. Albini, D.M. Noonan, Cytokines and chemokines as regulators of angiogenesis in health and disease, Curr. Pharm. Des. 12 (2006) 3101-3115.

[24] B.B. Aggarwal, S. Shishodia, S.K. Sandur, M.K. Pandey, G. Sethi, Inflammation and cancer: how hot is the link? Biochem. Pharmacol. 72 (2006) 1605-1621.

[25] C. Magnon, S.J. Hall, J. Lin, X. Xue, L. Gerber, S.J. Freedland, P.S. Frenette, Autonomic nerve development contributes to prostate cancer progression, Science (New York, N.Y.) 341 (2013) 1236361.

[26] R.E. Stopczynski, D.P. Normolle, D.J. Hartman, H. Ying, J.J. DeBerry, K. Bielefeldt, A.D. Rhim, R.A. DePinho, K.M. Albers, B.M. Davis, Neuroplastic changes occur early in the development of pancreatic ductal adenocarcinoma, Cancer Res. 74 (2014) 1718-1727.

[27] S.C. Peterson, M. Eberl, A.N. Vagnozzi, A. Belkadi, N.A. Veniaminova, M.E. Verhaegen, C.K. Bichakjian, N.L. Ward, A.A. Dlugosz, S.Y. Wong, Basal cell carcinoma preferentially arises from stem cells within hair follicle and mechanosensory niches, Cell Stem Cell 16 (2015) 400-412.

[28] C.-M. Zhao, Y. Hayakawa, Y. Kodama, S. Muthupalani, C.B. Westphalen, G.T. Andersen, A. Flatberg, H. Johannessen, R.A. Friedman, B.W. Renz, A.K. Sandvik, V. Beisvag, H. Tomita, A. Hara, M. Quante, Z. Li, M.D. Gershon, K. Kaneko, J.G. Fox, T.C. Wang, D. Chen, Denervation suppresses gastric tumorigenesis, Sci. Transl. Med. 6 (2014) (250ra115-250ra115).

[29] Y. Hayakawa, K. Sakitani, M. Konishi, S. Asfaha, R. Niikura, H. Tomita, B.W. Renz, Y. Tailor, M. Macchini, M. Middelhoff, Z. Jiang, T. Tanaka, Z.A. Dubeykovskaya, W. Kim, X. Chen, A.M. Urbanska, K. Nagar, C.B. Westphalen, M. Quante, C.S. Lin, M.D. Gershon, A. Hara, C.M. Zhao, D. Chen, D.L. Worthley, K. Koike, T.C. Wang, Nerve growth factor promotes gastric tumorigenesis through aberrant cholinergic signaling, Cancer Cell 31 (2017) 21-34.

[30] S. Gianino, J.R. Grider, J. Cresswell, H. Enomoto, R.O. Heuckeroth, GDNF availability determines enteric neuron number by controlling precursor proliferation, Development 130 (2003) 2187-2198.

[31] J.B. Furness, Types of neurons in the enteric nervous system, J. Auton. Nerv. Syst 81 (2000) 87-96.

[32] W.M. Bayliss, E.H. Starling, The movements and innervation of the small intestine, J. Physiol. 24 (1899) 99-143.

[33] J.B. Furness, C. Jones, K. Nurgali, N. Clerc, Intrinsic primary afferent neurons and nerve circuits within the intestine, Prog. Neurobiol. 72 (2004) 143-164.

[34] G.M. Mawe, Colitis-induced neuroplasticity disrupts motility in the inflamed and post-inflamed colon, J. Clin. Invest. 125 (2015) 949-955.

[35] J.D. Huizinga, J.H. Chen, Y.F. Zhu, A. Pawelka, R.J. McGinn, B.L. Bardakjian, S.P. Parsons, W.A. Kunze, R.Y. Wu, P. Bercik, A. Khoshdel, S. Chen, S. Yin, Q. Zhang, Y. Yu, Q. Gao, K. Li, X. Hu, N. Zarate, P. Collins, M. Pistilli, J. Ma, R. Zhang, D. Chen, The origin of segmentation motor activity in the intestine, Nat. Commun. 5 (2014) 3326.

[36] J.C. Bornstein, M. Costa, J.R. Grider, Enteric motor and interneuronal circuits controlling motility, Neurogastroenterol. Motil. 16 (Suppl. 1) (2004) 34-38.

[37] H.L. Cameron, M.H. Perdue, Muscarinic acetylcholine receptor activation increases transcellular transport of macromolecules across mouse and human intestinal epithelium in vitro, Neurogastroenterol. Motil. 19 (2007) 47-56.

[38] M. Neunlist, F. Toumi, T. Oreschkova, M. Denis, J. Leborgne, C.L. Laboisse, J.P. Galmiche, A. Jarry, Human ENS regulates the intestinal epithelial barrier permeability and a tight junction-associated protein ZO-1 via VIPergic pathways, Am. J. Physiol. Gastrointest. Liver Physiol. 285 (2003) G1028-1036.

[39] V.S. Conlin, X. Wu, C. Nguyen, C. Dai, B.A. Vallance, A.M. Buchan, L. Boyer, K. Jacobson, Vasoactive intestinal peptide ameliorates intestinal barrier disruption associated with Citrobacter rodentium-induced colitis, Am. J. Physiol. Gastrointest. Liver Physiol. 297 (2009) G735-750.

[40] D. Strassheim, L.G. May, K.A. Varker, H.L. Puhl, S.H. Phelps, R.A. Porter, R.S. Aronstam, J.D. Noti, C.L. Williams, M3 muscarinic acetylcholine receptors regulate cytoplasmic myosin by a process involving RhoA and requiring conventional protein kinase C isoforms, J. Biol. Chem. 274 (1999) 18675-18685.

[41] G.M. Mawe, J.M. Hoffman, Serotonin signalling in the gut-functions, dysfunctions and therapeutic targets, Nat. Rev. Gastroenterol. Hepatol. 10 (2013) 473-486.

[42] J.D. Wood, Enteric Nervous System (The Brain-in-the-gut), Morgan \& Claypool Life Sciences, Place Published, 2011.

[43] K. Cheng, R. Samimi, G. Xie, J. Shant, C. Drachenberg, M. Wade, R.J. Davis, G. Nomikos, J.P. Raufman, Acetylcholine release by human colon cancer cells mediates autocrine stimulation of cell proliferation, Am. J. Physiol. Gastrointest. Liver Physiol. 295 (2008) G591-597.

[44] T. Goode, T. O'Connor, A. Hopkins, D. Moriarty, G.C. O'Sullivan, J.K. Collins, D. O'Donoghue, A.W. Baird, J. O'Connell, F. Shanahan, Neurokinin-1 receptor (NK1R) expression is induced in human colonic epithelial cells by proinflammatory cytokines and mediates proliferation in response to substance P, J. Cell. Physiol. 197 (2003) 30-41.

[45] F. Toumi, M. Neunlist, E. Cassagnau, S. Parois, C.L. Laboisse, J.P. Galmiche, A. Jarry, Human submucosal neurones regulate intestinal epithelial cell proliferation: evidence from a novel co-culture model, Neurogastroenterol. Motil. 15 (2003) 239-242.

[46] X. Wu, V.S. Conlin, V. Morampudi, N.R. Ryz, Y. Nasser, G. Bhinder, K.S. Bergstrom, H.B. Yu, C.C.M. Waterhouse, A.M.J. Buchan, O.E. Popescu, W.T. Gibson, J.A. Waschek, B.A. Vallance, K. Jacobson, Vasoactive intestina 
polypeptide promotes intestinal barrier homeostasis and protection against colitis in mice, PLoS One 10 (2015) e0125225.

[47] E.R. Gross, M.D. Gershon, K.G. Margolis, Z.V. Gertsberg, Z. Li, R.A. Cowles, Neuronal serotonin regulates growth of the intestinal mucosa in mice, Gastroenterology 143 (2012) 408-417 (e402).

[48] K. Wright, N. Rooney, M. Feeney, J. Tate, D. Robertson, M. Welham, S. Ward, Differential expression of cannabinoid receptors in the human colon: cannabinoids promote epithelial wound healing, Gastroenterology 129 (2005) 437-453.

[49] X. Guan, H.E. Karpen, J. Stephens, J.T. Bukowski, S. Niu, G. Zhang, B. Stoll, M.J. Finegold, J.J. Holst, D. Hadsell, B.L. Nichols, D.G. Burrin, GLP-2 receptor localizes to enteric neurons and endocrine cells expressing vasoactive peptides and mediates increased blood flow, Gastroenterology 130 (2006) 150-164.

[50] R.K. Goyal, I. Hirano, The enteric nervous system, N. Engl. J. Med. 334 (1996) $1106-1115$.

[51] R.H. Straub, R. Wiest, U.G. Strauch, P. Harle, J. Scholmerich, The role of the sympathetic nervous system in intestinal inflammation, Gut 55 (2006) 1640-1649.

[52] W. Pawlik, D. Mailman, L.L. Shanbour, E.D. Jacobson, Dopamine effects on the intestinal circulation, Am. Heart J. 91 (1976) 325-331.

[53] S. Han, C.L. Yang, X. Chen, L. Naes, B.F. Cox, T. Westfall, Direct evidence for the role of neuropeptide $\mathrm{Y}$ in sympathetic nerve stimulation-induced vasoconstriction, Am. J. Phys. 274 (1998) H290-294.

[54] C.J. Lewis, R.J. Evans, T.O. Neild, Inhibition of vasoconstriction and Ca2 + currents mediated by neuropeptide Y Y2 receptors, J. Smooth Muscle Res. 35 (1999) $147-156$.

[55] K.G. Margolis, K. Stevanovic, N. Karamooz, Z.S. Li, A. Ahuja, F. D'Autreaux, V. Saurman, A. Chalazonitis, M.D. Gershon, Enteric neuronal density contributes to the severity of intestinal inflammation, Gastroenterology 141 (2011) 588-598 (598 e581-582).

[56] E. Ekblad, A.J. Bauer, Role of vasoactive intestinal peptide and inflammatory mediators in enteric neuronal plasticity, Neurogastroenterol. Motil. 16 (Suppl. 1) (2004) 123-128.

[57] M.B. Arciszewski, E. Sand, E. Ekblad, Vasoactive intestinal peptide rescues cultured rat myenteric neurons from lipopolysaccharide induced cell death, Regul. Pept. 146 (2008) 218-223.

[58] D.L. Sigalet, L. Wallace, E. De Heuval, K.A. Sharkey, The effects of glucagon-like peptide 2 on enteric neurons in intestinal inflammation, Neurogastroenterol. Motil. 22 (2010) 1318-e1350.

[59] N. El-Jamal, E. Erdual, M. Neunlist, D. Koriche, C. Dubuquoy, F. Maggiotto, J. Chevalier, D. Berrebi, L. Dubuquoy, E. Boulanger, A. Cortot, P. Desreumaux, Glugacon-like peptide-2: broad receptor expression, limited therapeutic effect on intestinal inflammation and novel role in liver regeneration, Am. J. Physiol. Gastrointest. Liver Physiol. 307 (2014) G274-285.

[60] D.J. Drucker, B. Yusta, R.P. Boushey, L. DeForest, P.L. Brubaker, Human $\left[\mathrm{Gly}^{2}\right]$ GLP-2 reduces the severity of colonic injury in a murine model of experimental colitis, Am. J. Physiol. Gastrointest. Liver Physiol. 276 (1999) G79-G91.

[61] N. Nemetz, C. Abad, G. Lawson, H. Nobuta, S. Chhith, L. Duong, G. Tse, J. Braun, J.A. Waschek, Induction of colitis and rapid development of colorectal tumors in mice deficient in the neuropeptide PACAP, Int. J. Cancer 122 (2008) 1803-1809.

[62] E. Talero, S. Sanchez-Fidalgo, J.R. Calvo, V. Motilva, Chronic administration of galanin attenuates the TNBS-induced colitis in rats, Regul. Pept. 141 (2007) 96-104.

[63] E. Talero, S. Sanchez-Fidalgo, J. Ramon Calvo, V. Motilva, Galanin in the trinitrobenzene sulfonic acid rat model of experimental colitis, Int. Immunopharmacol. 6 (2006) 1404-1412.

[64] G.X. Liu, Y.X. Yang, J. Yan, T. Zhang, Y.P. Zou, X.L. Huang, H.T. Gan, Glial-derived neurotrophic factor reduces inflammation and improves delayed colonic transit in rat models of dextran sulfate sodium-induced colitis, Int. Immunopharmacol. 19 (2014) 145-152.

[65] M.G. Welch, K.G. Margolis, Z. Li, M.D. Gershon, Oxytocin regulates gastrointestinal motility, inflammation, macromolecular permeability, and mucosal maintenance in mice, Am. J. Physiol. Gastrointest. Liver Physiol. 307 (2014) G848-862.

[66] A.G. Le Loupp, K. Bach-Ngohou, A. Bourreille, H. Boudin, M. Rolli-Derkinderen, M.G. Denis, M. Neunlist, D. Masson, Activation of the prostaglandin D2 metabolic pathway in Crohn's disease: involvement of the enteric nervous system, BMC Gastroenterol. 15 (2015) 112

[67] R. Eliakim, F. Karmeli, E. Okon, D. Rachmilewitz, Octreotide effectively decreases mucosal damage in experimental colitis, Gut 34 (1993) 264-269.

[68] X. Li, L. Cai, H. Xu, C. Geng, J. Lu, L. Tao, D. Sun, F.K. Ghishan, C. Wang, Somatostatin regulates NHE8 protein expression via the ERK1/2 MAPK pathway in DSS-induced colitis mice, Am. J. Physiol. Gastrointest. Liver Physiol. 311 (2016) G954-G963.

[69] R. Pacheco, F. Contreras, M. Zouali, The dopaminergic system in autoimmune diseases, Front. Immunol. 5 (2014) 117.

[70] J.T. Dudley, M. Sirota, M. Shenoy, R.K. Pai, S. Roedder, A.P. Chiang, A.A. Morgan, M.M. Sarwal, P.J. Pasricha, A.J. Butte, Computational repositioning of the anticonvulsant topiramate for inflammatory bowel disease, Sci. Transl. Med. (7) (2011) 96ra76.

[71] K. Bakirtzi, I.K. Law, X. Xue, D. Iliopoulos, Y.M. Shah, C. Pothoulakis, Neurotensin promotes the development of colitis and intestinal angiogenesis via Hif-1alphamiR-210 signaling, J. Immunol. 196 (2016) 4311-4321.

[72] H.W. Koon, C. Pothoulakis, Immunomodulatory properties of substance P: the gastrointestinal system as a model, Ann. N. Y. Acad. Sci. 1088 (2006) 23-40.

[73] S. Haub, Y. Ritze, I. Bergheim, O. Pabst, M.D. Gershon, S.C. Bischoff, Enhancement of intestinal inflammation in mice lacking interleukin 10 by deletion of the serotonin reuptake transporter, Neurogastroenterol. Motil. 22 (2010) 826-834 (e229).

[74] M. El-Salhy, T. Hausken, The role of the neuropeptide Y (NPY) family in the pathophysiology of inflammatory bowel disease (IBD), Neuropeptides (2015).

[75] B. Chandrasekharan, S. Jeppsson, S. Pienkowski, D.D. Belsham, S.V. Sitaraman, D. Merlin, E. Kokkotou, A. Nusrat, M.G. Tansey, S. Srinivasan, Tumor necrosis factor-neuropeptide Y cross talk regulates inflammation, epithelial barrier functions, and colonic motility, Inflamm. Bowel Dis. 19 (2013) 2535-2546.

[76] A. Lin, S. Lourenssen, R.D. Stanzel, M.G. Blennerhassett, Selective loss of NGFsensitive neurons following experimental colitis, Exp. Neurol. 191 (2005) 337-343.

[77] P.A. Muller, B. Koscsó, G.M. Rajani, K. Stevanovic, M.-L. Berres, D. Hashimoto, A. Mortha, M. Leboeuf, X.-M. Li, D. Mucida, E.R. Stanley, S. Dahan, K.G. Margolis, M.D. Gershon, M. Merad, M. Bogunovic, Crosstalk between muscularis macrophages and enteric neurons regulates gastrointestinal motility, Cell 158 (2014) 300-313.

[78] I. Gabanyi, P.A. Muller, L. Feighery, T.Y. Oliveira, F.A. Costa-Pinto, D. Mucida, Neuro-immune interactions drive tissue programming in intestinal macrophages, Cell 164 (2016) 378-391.

[79] T. Colangelo, G. Polcaro, L. Muccillo, G. D'Agostino, V. Rosato, P. Ziccardi, A. Lupo, G. Mazzoccoli, L. Sabatino, V. Colantuoni, Friend or foe?: the tumour microenvironment dilemma in colorectal cancer, Biochim. Biophys. Acta 1867 (2017) 1-18.

[80] L.A. Feagins, R.F. Souza, S.J. Spechler, Carcinogenesis in IBD: potential targets for the prevention of colorectal cancer, Nat. Rev. Gastroenterol. Hepatol. 6 (2009) 297-305.

[81] P.L. Lakatos, L. Lakatos, Risk for colorectal cancer in ulcerative colitis: changes, causes and management strategies, World J. Gastroenterol. 14 (2008) 3937-3947.

[82] J. Terzic, S. Grivennikov, E. Karin, M. Karin, Inflammation and colon cancer, Gastroenterology 138 (2010) 2101-2114 (e2105).

[83] L.B. Meira, J.M. Bugni, S.L. Green, C.-W. Lee, B. Pang, D. Borenshtein, B.H. Rickman, A.B. Rogers, C.A. Moroski-Erkul, J.L. McFaline, D.B. Schauer, P.C. Dedon, J.G. Fox, L.D. Samson, DNA damage induced by chronic inflammation contributes to colon carcinogenesis in mice, J. Clin. Invest. 118 (2008) $2516-2525$.

[84] S.P. Hussain, L.J. Hofseth, C.C. Harris, Radical causes of cancer, Nat. Rev. Cancer 3 (2003) 276-285.

[85] F. Colotta, P. Allavena, A. Sica, C. Garlanda, A. Mantovani, Cancer-related inflammation, the seventh hallmark of cancer: links to genetic instability, Carcinogenesis 30 (2009) 1073-1081.

[86] M.A. Hahn, T. Hahn, D.H. Lee, R.S. Esworthy, B.W. Kim, A.D. Riggs, F.F. Chu, G.P. Pfeifer, Methylation of polycomb target genes in intestinal cancer is mediated by inflammation, Cancer Res. 68 (2008) 10280-10289.

[87] D. Iliopoulos, H.A. Hirsch, K. Struhl, An epigenetic switch involving NF-kappaB, Lin28, Let-7 MicroRNA, and IL6 links inflammation to cell transformation, Cell 139 (2009) 693-706.

[88] K. Oguma, H. Oshima, M. Aoki, R. Uchio, K. Naka, S. Nakamura, A. Hirao, H. Saya, M.M. Taketo, M. Oshima, Activated macrophages promote Wnt signalling through tumour necrosis factor-alpha in gastric tumour cells, EMBO J. 27 (2008) 1671-1681.

[89] M.D. Castellone, H. Teramoto, B.O. Williams, K.M. Druey, J.S. Gutkind, Prostaglandin E2 promotes colon cancer cell growth through a Gs-axin-beta-catenin signaling axis, Science (New York, N.Y.) 310 (2005) 1504-1510.

[90] P. Kaler, B.N. Godasi, L. Augenlicht, L. Klampfer, The NF-kappaB/AKT-dependent induction of Wnt signaling in colon cancer cells by macrophages and IL-1beta, Cancer Microenviron. 2 (2009) 69-80.

[91] M. Karin, Nuclear factor-kappaB in cancer development and progression, Nature 441 (2006) 431-436.

[92] S. Wang, Z. Liu, L. Wang, X. Zhang, NF-kappaB signaling pathway, inflammation and colorectal cancer, Cell. Mol. Immunol. 6 (2009) 327-334.

[93] B.K. Popivanova, K. Kitamura, Y. Wu, T. Kondo, T. Kagaya, S. Kaneko, M. Oshima, C. Fujii, N. Mukaida, Blocking TNF-alpha in mice reduces colorectal carcinogenesis associated with chronic colitis, J. Clin. Invest. 118 (2008) 560-570.

[94] S. Grivennikov, E. Karin, J. Terzic, D. Mucida, G.Y. Yu, S. Vallabhapurapu, J. Scheller, S. Rose-John, H. Cheroutre, L. Eckmann, M. Karin, IL-6 and Stat3 are required for survival of intestinal epithelial cells and development of colitis-associated cancer, Cancer Cell 15 (2009) 103-113.

[95] R. Atreya, J. Mudter, S. Finotto, J. Mullberg, T. Jostock, S. Wirtz, M. Schutz, B. Bartsch, M. Holtmann, C. Becker, D. Strand, J. Czaja, J.F. Schlaak, H.A. Lehr, F. Autschbach, G. Schurmann, N. Nishimoto, K. Yoshizaki, H. Ito, T. Kishimoto, P.R. Galle, S. Rose-John, M.F. Neurath, Blockade of interleukin 6 trans signaling suppresses T-cell resistance against apoptosis in chronic intestinal inflammation: evidence in crohn disease and experimental colitis in vivo, Nat. Med. 6 (2000) 583-588.

[96] F. Balkwill, Tumour necrosis factor and cancer, Nat. Rev. Cancer 9 (2009) 361-371.

[97] G. Kollias, Modeling the function of tumor necrosis factor in immune pathophysiology, Autoimmun. Rev. 3 (Suppl. 1) (2004) S24-25.

[98] C.G. Peterson, P. Sangfelt, M. Wagner, T. Hansson, H. Lettesjo, M. Carlson, Fecal levels of leukocyte markers reflect disease activity in patients with ulcerative colitis, Scand. J. Clin. Lab. Invest. 67 (2007) 810-820.

[99] H. Xiao, M.F. Gulen, J. Qin, J. Yao, K. Bulek, D. Kish, C.Z. Altuntas, D. Wald, C. Ma, H. Zhou, V.K. Tuohy, R.L. Fairchild, C. de la Motte, D. Cua, B.A. Vallance, $\mathrm{X}$. Li, The toll-interleukin-1 receptor member SIGIRR regulates colonic epithelial homeostasis, inflammation, and tumorigenesis, Immunity 26 (2007) 461-475.

[100] Y. Wu, B.P. Zhou, Inflammation: a driving force speeds cancer metastasis, Cell Cycle 8 (2009) 3267-3273. 
[101] D.C. Rubin, A. Shaker, M.S. Levin, Chronic intestinal inflammation: inflammatory bowel disease and colitis-associated colon cancer, Front. Immunol. 3 (2012) 107.

[102] L. Van Der Kraak, P. Gros, N. Beauchemin, Colitis-associated colon cancer: is it in your genes? World J. Gastroenterol. 21 (2015) 11688-11699.

[103] J.E. Axelrad, S. Lichtiger, V. Yajnik, Inflammatory bowel disease and cancer: the role of inflammation, immunosuppression, and cancer treatment, World J. Gastroenterol. 22 (2016) 4794-4801.

[104] S. Sanovic, D.P. Lamb, M.G. Blennerhassett, Damage to the enteric nervous system in experimental colitis, Am. J. Pathol. 155 (1999) 1051-1057.

[105] S. Venkataramana, S. Lourenssen, K.G. Miller, M.G. Blennerhassett, Early inflammatory damage to intestinal neurons occurs via inducible nitric oxide synthase, Neurobiol. Dis. 75 (2015) 40-52.

[106] D.R. Linden, J.M. Couvrette, A. Ciolino, C. McQuoid, H. Blaszyk, K.A. Sharkey, G.M. Mawe, Indiscriminate loss of myenteric neurones in the TNBS-inflamed guinea-pig distal colon, Neurogastroenterol. Motil. 17 (2005) 751-760.

[107] B.D. Gulbransen, M. Bashashati, S.A. Hirota, X. Gui, J.A. Roberts, J.A. MacDonald, D.A. Muruve, D.M. McKay, P.L. Beck, G.M. Mawe, R.J. Thompson, K.A. Sharkey, Activation of neuronal P2X7 receptor-pannexin-1 mediates death of enteric neurons during colitis, Nat. Med. 18 (2012) 600-604.

[108] N. Bernardini, C. Segnani, C. Ippolito, R. De Giorgio, R. Colucci, M.S. FaussonePellegrini, M. Chiarugi, D. Campani, M. Castagna, L. Mattii, C. Blandizzi, A. Dolfi, Immunohistochemical analysis of myenteric ganglia and interstitial cells of Cajal in ulcerative colitis, J. Cell. Mol. Med. 16 (2012) 318-327.

[109] S.H.A. Li, Y. Sun, D. Gao, Role of the nervous system in cancer metastasis, Oncol. Lett. 5 (2013) 1101-1111.

[110] C. Liebig, G. Ayala, J. Wilks, G. Verstovsek, H. Liu, N. Agarwal, D.H. Berger, D. Albo, Perineural invasion is an independent predictor of outcome in colorectal cancer, J. Clin. Oncol. Off. J. Am. Soc. Clin. Oncol. 27 (2009) 5131-5137.

[111] D. Albo, C.L. Akay, C.L. Marshall, J.A. Wilks, G. Verstovsek, H. Liu, N. Agarwal, D.H. Berger, G.E. Ayala, Neurogenesis in colorectal cancer is a marker of aggressive tumor behavior and poor outcomes, Cancer 117 (2011) 4834-4845.

[112] D. Huang, S. Su, X. Cui, X. Shen, Y. Zeng, W. Wu, J. Chen, F. Chen, C. He, J. Liu, W. Huang, Q. Liu, F. Su, E. Song, N. Ouyang, Nerve fibers in breast cancer tissues indicate aggressive tumor progression, Medicine 93 (2014) e172.

[113] A. Bilici, M. Seker, B.B. Ustaalioglu, U. Kefeli, E. Yildirim, D. Yavuzer, F.M. Aydin, T. Salepci, M. Oncel, M. Gumus, Prognostic significance of perineural invasion in patients with gastric cancer who underwent curative resection, Ann. Surg. Oncol. 17 (2010) 2037-2044.

[114] T. Hibi, T. Mori, M. Fukuma, K. Yamazaki, A. Hashiguchi, T. Yamada, M. Tanabe, K. Aiura, T. Kawakami, A. Ogiwara, T. Kosuge, M. Kitajima, Y. Kitagawa, M. Sakamoto, Synuclein-gamma is closely involved in perineural invasion and distant metastasis in mouse models and is a novel prognostic factor in pancreatic cancer, Clin. Cancer Res. 15 (2009) 2864-2871.

[115] S.G. Karak, N. Quatrano, J. Buckley, A. Ricci Jr., Prevalence and significance of perineural invasion in invasive breast carcinoma, Conn. Med. 74 (2010) 17-21.

[116] A. Meinel, U. Fischer, K. Bilek, B. Hentschel, L.C. Horn, Morphological parameters associated with perineural invasion (PNI) in carcinoma of the cervix uteri, Int. J. Surg. Pathol. 19 (2011) 159-163.

[117] L.C. Horn, A. Meinel, U. Fischer, K. Bilek, B. Hentschel, Perineural invasion in carcinoma of the cervix uteri-prognostic impact, J. Cancer Res. Clin. Oncol. 136 (2010) 1557-1562.

[118] L. Tianhang, F. Guoen, B. Jianwei, M. Liye, The effect of perineural invasion on overall survival in patients with gastric carcinoma, J. Gastrointest. Surg. 12 (2008) 1263-1267.

[119] J. Peng, W. Sheng, D. Huang, A.P. Venook, Y. Xu, Z. Guan, S. Cai, Perineural invasion in pT3N0 rectal cancer: the incidence and its prognostic effect, Cancer 117 (2011) 1415-1421.

[120] J.-W. Chen, J.-D. Xie, Y.-H. Ling, P. Li, S.-M. Yan, S.-Y. Xi, R.-Z. Luo, J.-P. Yun, D. Xie, M.-Y. Cai, The prognostic effect of perineural invasion in esophageal squamous cell carcinoma, BMC Cancer 14 (2014) 1-7.

[121] E.M. Poeschl, M.J. Pollheimer, P. Kornprat, R.A. Lindtner, A. Schlemmer, P. Rehak, M. Vieth, C. Langner, Perineural invasion: correlation with aggressive phenotype and independent prognostic variable in both colon and rectum cancer, J. Clin. Oncol. Off. J. Am. Soc. Clin. Oncol. 28 (2010) e358-360 (author reply e361-352).

[122] J.W. Huh, H.R. Kim, Y.J. Kim, Prognostic value of perineural invasion in patients with stage II colorectal cancer, Ann. Surg. Oncol. 17 (2010) 2066-2072.

[123] F. Di Fabio, R. Nascimbeni, V. Villanacci, C. Baronchelli, D. Bianchi, G. Fabbretti, C. Casella, B. Salerni, Prognostic variables for cancer-related survival in nodenegative colorectal carcinomas, Dig. Surg. 21 (2004) 128-133.

[124] G. Burdy, Y. Panis, A. Alves, J. Nemeth, A. Lavergne-Slove, P. Valleur, Identifying patients with T3-T4 node-negative colon cancer at high risk of recurrence, Dis. Colon Rectum 44 (2001) 1682-1688.

[125] N. Knijn, S.C. Mogk, S. Teerenstra, F. Simmer, I.D. Nagtegaal, Perineural invasion is a strong prognostic factor in colorectal cancer: a systematic review, Am. J. Surg. Pathol. 40 (2016) 103-112.

[126] J.W. Huh, J.H. Lee, H.R. Kim, Y.J. Kim, Prognostic significance of lymphovascular or perineural invasion in patients with locally advanced colorectal cancer, Am. J. Surg. 206 (2013) 758-763.

[127] F. Liebl, I.E. Demir, R. Rosenberg, A. Boldis, E. Yildiz, K. Kujundzic, T. Kehl, D. Dischl, T. Schuster, M. Maak, K. Becker, R. Langer, M. Laschinger, H. Friess, G.O. Ceyhan, The severity of neural invasion is associated with shortened survival in colon cancer, Clin. Cancer Res. 19 (2013) 50-61.

[128] M. Mancino, E. Ametller, P. Gascón, V. Almendro, The neuronal influence on tumor progression, Biochim. Biophys. Acta, Rev. Cancer 1816 (2011) 105-118.

[129] L. Dolle, I. El Yazidi-Belkoura, E. Adriaenssens, V. Nurcombe, H. Hondermarck,
Nerve growth factor overexpression and autocrine loop in breast cancer cells, Oncogene 22 (2003) 5592-5601.

[130] A.A. Geldof, E.P. Van Haarst, D.W. Newling, Neurotrophic factors in prostate and prostatic cancer, Prostate Cancer Prostatic Dis. 1 (1998) 236-241.

[131] A. Chedotal, G. Kerjan, C. Moreau-Fauvarque, The brain within the tumor: new roles for axon guidance molecules in cancers, Cell Death Differ. 12 (2005) 1044-1056.

[132] F. Entschladen, D. Palm, K. Lang, T.L. Drell Iv, K.S. Zaenker, Neoneurogenesis: tumors may initiate their own innervation by the release of neurotrophic factors in analogy to lymphangiogenesis and neoangiogenesis, Med. Hypotheses 67 (2006) 33-35.

[133] Q. Zhao, Y. Yang, X. Liang, G. Du, L. Liu, L. Lu, J. Dong, H. Han, G. Zhang, The clinicopathological significance of neurogenesis in breast cancer, BMC Cancer 14 (2014) 484.

[134] D. He, A. Manzoni, D. Florentin, W. Fisher, Y. Ding, M. Lee, G. Ayala, Biologic effect of neurogenesis in pancreatic cancer, Hum. Pathol. 52 (2016) 182-189.

[135] C.B. Westphalen, S. Asfaha, Y. Hayakawa, Y. Takemoto, D.J. Lukin, A.H. Nuber, A. Brandtner, W. Setlik, H. Remotti, A. Muley, X. Chen, R. May, C.W. Houchen, J.G. Fox, M.D. Gershon, M. Quante, T.C. Wang, Long-lived intestinal tuft cells serve as colon cancer-initiating cells, J. Clin. Invest. 124 (2014) 1283-1295.

[136] M. Monje, Settling a nervous stomach: the neural regulation of enteric cancer, Cancer Cell 31 (2017) 1-2.

[137] V. Melotte, M.H. Lentjes, S.M. van den Bosch, D.M. Hellebrekers, J.P. de Hoon, K.A. Wouters, K.L. Daenen, I.E. Partouns-Hendriks, F. Stessels, J. Louwagie, K.M. Smits, M.P. Weijenberg, S. Sanduleanu, C.A. Khalid-de Bakker, F.A. Oort, G.A. Meijer, D.M. Jonkers, J.G. Herman, A.P. de Bruine, M. van Engeland, N-Myc downstream-regulated gene 4 (NDRG4): a candidate tumor suppressor gene and potential biomarker for colorectal cancer, J. Natl. Cancer Inst. 101 (2009) 916-927.

[138] T.F. Imperiale, D.F. Ransohoff, S.H. Itzkowitz, T.R. Levin, P. Lavin, G.P. Lidgard, D.A. Ahlquist, B.M. Berger, Multitarget stool DNA testing for colorectal-cancer screening, N. Engl. J. Med. 370 (2014) 1287-1297.

[139] N. Vaes, M.H. Lentjes, M. Gijbels, G. Rademakers, K.L. Daenen, W. Boesmans, K.A. Wouters, A. Geuzens, X. Qu, H.P.J. Steinbusch, B.P. Rutten, H.S. Baldwin, K.A. Sharkey, R.M. Hofstra, M. Van Engeland, P. Vanden Berghe, V. Melotte, NDRG4, an early detection marker for colorectal cancer, is specifically expressed in enteric neurons, Neurogastroenterol. Motil. (2017).

[140] E.C. Benesh, P.M. Miller, E.R. Pfaltzgraff, N.E. Grega-Larson, H.A. Hager, B.H. Sung, X. Qu, H.S. Baldwin, A.M. Weaver, D.M. Bader, Bves and NDRG4 regulate directional epicardial cell migration through autocrine extracellular matrix deposition, Mol. Biol. Cell 24 (2013) 3496-3510.

[141] L. Fontenas, F. De Santis, V. Di Donato, C. Degerny, B. Chambraud, F. Del Bene, M. Tawk, Neuronal Ndrg4 is essential for nodes of Ranvier Organization in Zebrafish, PLoS Genet. 12 (2016) e1006459.

[142] S.B. Garcia, A.L. Aranha, F.R. Garcia, F.V. Basile, A.P. Pinto, E.C. de Oliveira, S. Zucoloto, A retrospective study of histopathological findings in 894 cases of megacolon: what is the relationship between megacolon and colonic cancer? Rev. Inst. Med. Trop. Sao Paulo 45 (2003) 91-93.

[143] M.V. Vespucio, A. Turatti, P. Modiano, E.C. Oliveira, S.R. Chicote, A.M. Pinto, S.B. Garcia, Intrinsic denervation of the colon is associated with a decrease of some colonic preneoplastic markers in rats treated with a chemical carcinogen, Braz. J. Med. Biol. Res. 41 (2008) 311-317.

[144] S.Y. Ko, C.R. Dass, K. Nurgali, Netrin-1 in the developing enteric nervous system and colorectal cancer, Trends Mol. Med. 18 (2012) 544-554.

[145] E.M. Ratcliffe, L. Fan, T.J. Mohammed, M. Anderson, A. Chalazonitis, M.D. Gershon, Enteric neurons synthesize netrins and are essential for the development of the vagal sensory innervation of the fetal gut, Dev. Neurobiol. 71 (2011) 362-373.

[146] C. Seaman, R. Anderson, B. Emery, H.M. Cooper, Localization of the netrin guidance receptor, DCC, in the developing peripheral and enteric nervous systems, Mech. Dev. 103 (2001) 173-175.

[147] M. Castets, L. Broutier, Y. Molin, M. Brevet, G. Chazot, N. Gadot, A. Paquet, L. Mazelin, L. Jarrosson-Wuilleme, J.-Y. Scoazec, A. Bernet, P. Mehlen, DCC constrains tumour progression via its dependence receptor activity, Nature 482 (2012) 534-537.

[148] L. Mazelin, A. Bernet, C. Bonod-Bidaud, L. Pays, S. Arnaud, C. Gespach, D.E. Bredesen, J.Y. Scoazec, P. Mehlen, Netrin-1 controls colorectal tumorigenesis by regulating apoptosis, Nature 431 (2004) 80-84.

[149] P. Mehlen, C. Furne, Netrin-1: when a neuronal guidance cue turns out to be a regulator of tumorigenesis, Cell. Mol. Life Sci. 62 (2005) 2599-2616.

[150] J. Godlewski, Morphological changes in the enteric nervous system caused by carcinoma of the human large intestine, Folia Histochem. Cytobiol. 48 (2010) $157-162$.

[151] J. Godlewski, I.M. Lakomy, Changes in vasoactive intestinal peptide, pituitary adenylate cyclase-activating polypeptide and neuropeptide Y-ergic structures of the enteric nervous system in the carcinoma of the human large intestine, Folia Histochem. Cytobiol. 48 (2010) 208-216.

[152] J. Godlewski, J. Kaleczyc, Somatostatin, substance P and calcitonin gene-related peptide-positive intramural nerve structures of the human large intestine affected by carcinoma, Folia Histochem. Cytobiol. 48 (2010) 475-483.

[153] J. Godlewski, Z. Pidsudko, Characteristic of galaninergic components of the enteric nervous system in the cancer invasion of human large intestine, Ann. Anat. 194 (2012) 368-372.

[154] B. Sitohy, M. El-Salhy, Changes in the colonic enteric nervous system in rats with chemically induced colon dysplasia and carcinoma, Acta Oncol. 41 (2002) 543-549. 
[155] H.M. Schuller, Neurotransmission and cancer: implications for prevention and therapy, Anti-Cancer Drugs 19 (2008) 655-671.

[156] Z.J. Li, C.H. Cho, Neurotransmitters, more than meets the eye-neurotransmitters and their perspectives in cancer development and therapy, Eur. J. Pharmacol. 667 (2011) 17-22.

[157] C. Alleaume, A. Eychene, E. Caigneaux, J.M. Muller, M. Philippe, Vasoactive intestinal peptide stimulates proliferation in HT29 human colonic adenocarcinoma cells: concomitant activation of Ras/Rap1-B-Raf-ERK signalling pathway, Neuropeptides 37 (2003) 98-104.

[158] H. Iishi, M. Tatsuta, M. Baba, S. Okuda, H. Taniguchi, Enhancement by vasoactive intestinal peptide of experimental carcinogenesis induced by azoxymethane in rat colon, Cancer Res. 47 (1987) 4890-4893.

[159] A. Levy, R. Gal, R. Granoth, Z. Dreznik, M. Fridkin, I. Gozes, In vitro and in vivo treatment of colon cancer by VIP antagonists, Regul. Pept. 109 (2002) 127-133.

[160] M. Ogasawara, J. Murata, K. Ayukawa, I. Saiki, Differential effect of intestinal neuropeptides on invasion and migration of colon carcinoma cells in vitro, Cancer Lett. 119 (1997) 125-130.

[161] L. Gamet, J.C. Murat, A. Remaury, C. Remesy, P. Valet, H. Paris, C. Denis-Pouxviel, Vasoactive intestinal peptide and forskolin regulate proliferation of the HT29 human colon adenocarcinoma cell line, J. Cell. Physiol. 150 (1992) 501-509.

[162] V. Lelievre, A.C. Meunier, E. Caigneaux, J. Falcon, J.M. Muller, Differential expression and function of PACAP and VIP receptors in four human colonic adenocarcinoma cell lines, Cell. Signal. 10 (1998) 13-26.

[163] N.M. Sherwood, S.L. Krueckl, J.E. McRory, The origin and function of the pituitary adenylate cyclase-activating polypeptide (PACAP)/glucagon superfamily, Endocr. Rev. 21 (2000) 619-670.

[164] N. Lu, R. Zhou, E. DiCicco-Bloom, Opposing mitogenic regulation by PACAP in sympathetic and cerebral cortical precursors correlates with differential expression of PACAP receptor (PAC1-R) isoforms, J. Neurosci. Res. 53 (1998) 651-662.

[165] F. Esteban, M. Munoz, M.A. Gonzalez-Moles, M. Rosso, A role for substance P in cancer promotion and progression: a mechanism to counteract intracellular death signals following oncogene activation or DNA damage, Cancer Metastasis Rev. 25 (2006) 137-145.

[166] M. Rosso, M.J. Robles-Frias, R. Covenas, M.V. Salinas-Martin, M. Munoz, The NK-1 receptor is expressed in human primary gastric and colon adenocarcinomas and is involved in the antitumor action of L-733,060 and the mitogenic action of substance P on human gastrointestinal cancer cell lines, Tumour Biol. 29 (2008) 245-254.

[167] C. Mayordomo, S. Garcia-Recio, E. Ametller, P. Fernandez-Nogueira, E.M. PastorArroyo, L. Vinyals, I. Casas, P. Gascon, V. Almendro, Targeting of substance P induces cancer cell death and decreases the steady state of EGFR and Her2, J. Cell. Physiol. 227 (2012) 1358-1366.

[168] A. Garnier, J. Vykoukal, J. Hubertus, E. Alt, D. von Schweinitz, R. Kappler, M. Berger, M. Ilmer, Targeting the neurokinin-1 receptor inhibits growth of human colon cancer cells, Int. J. Oncol. 47 (2015) 151-160.

[169] M. Munoz, R. Covenas, Neurokinin-1 receptor: a new promising target in the treatment of cancer, Discov. Med. 10 (2010) 305-313.

[170] M. Munoz, M. Rosso, The NK-1 receptor antagonist aprepitant as a broad spectrum antitumor drug, Investig. New Drugs 28 (2010) 187-193.

[171] M. Munoz, M. Rosso, R. Covenas, A new frontier in the treatment of cancer: NK-1 receptor antagonists, Curr. Med. Chem. 17 (2010) 504-516.

[172] A.B. Alfieri, L.X. Cubeddu, Role of NK1 receptors on cisplatin-induced nephrotoxicity in the rat, Naunyn Schmiedeberg's Arch. Pharmacol. 361 (2000) 334-338.

[173] R.M. Navari, Aprepitant: a neurokinin-1 receptor antagonist for the treatment of chemotherapy-induced nausea and vomiting, Expert. Rev. Anticancer. Ther. 4 (2004) 715-724.

[174] P.J. Tutton, D.H. Barkla, Influence of inhibitors of serotonin uptake on intestinal epithelium and colorectal carcinomas, Br. J. Cancer 46 (1982) 260-265.

[175] W. Xu, H. Tamim, S. Shapiro, M.R. Stang, J.-P. Collet, Use of antidepressants and risk of colorectal cancer: a nested case-control study, Lancet Oncol. 7 (2006) 301-308.

[176] P.F. Coogan, B.L. Strom, L. Rosenberg, Antidepressant use and colorectal cancer risk, Pharmacoepidemiol. Drug Saf. 18 (2009) 1111-1114.

[177] J. Chubak, D.M. Boudreau, S.J. Rulyak, M.T. Mandelson, Colorectal cancer risk in relation to antidepressant medication use, Int. J. Cancer 128 (2011) 227-232.

[178] D.P. Cronin-Fenton, A.H. Riis, T.L. Lash, S.O. Dalton, S. Friis, D. Robertson, H.T. Sorensen, Antidepressant use and colorectal cancer risk: a Danish populationbased case-control study, Br. J. Cancer 104 (2011) 188-192.

[179] D.H. Barkla, P.J. Tutton, Influence of histamine and serotonin antagonists on the growth of xenografted human colorectal tumors, J. Natl. Cancer Inst. 67 (1981) $1207-1211$.

[180] R. Ataee, S. Ajdary, M. Zarrindast, M. Rezayat, M.R. Hayatbakhsh, Anti-mitogenic and apoptotic effects of 5-HT1B receptor antagonist on HT29 colorectal cancer cell line, J. Cancer Res. Clin. Oncol. 136 (2010) 1461-1469.

[181] R. Ataee, S. Ajdary, M. Rezayat, M.A. Shokrgozar, S. Shahriari, M.R. Zarrindast, Study of 5HT3 and HT4 receptor expression in HT29 cell line and human colon adenocarcinoma tissues, Arch. Iran. Med. 13 (2010) 120-125.

[182] D. Julius, T. Livelli, T. Jessell, R. Axel, Ectopic expression of the serotonin 1c receptor and the triggering of malignant transformation, Science (New York, N.Y.) 244 (1989) 1057-1062.

[183] C. Sarkar, D. Chakroborty, Abstract 5354: Neuropeptide Y as a Prognostic Marker of Colorectal Cancer, American Association for Cancer Research (AACR) Annual MeetingSan Diego, (2014).

[184] V. Gotzos, B. Schwaller, J.C. Gander, M. Bustos-Castillo, M.R. Celio, Heterogeneity of expression of the calcium-binding protein calretinin in human colonic cancer cell lines, Anticancer Res. 16 (1996) 3491-3498.

[185] R. Cargnello, M.R. Celio, B. Schwaller, V. Gotzos, Change of calretinin expression in the human colon adenocarcinoma cell line HT29 after differentiation, Biochim. Biophys. Acta 1313 (1996) 201-208.

[186] V. Gotzos, E.S. Wintergerst, J.P. Musy, H.P. Spichtin, C.Y. Genton, Selective distribution of calretinin in adenocarcinomas of the human colon and adjacent tissues, Am. J. Surg. Pathol. 23 (1999) 701-711.

[187] P.H. Thaker, K. Yokoi, N.B. Jennings, Y. Li, R.B. Rebhun, D.L. Rousseau Jr., D. Fan, A.K. Sood, Inhibition of experimental colon cancer metastasis by the GABA-receptor agonist nembutal, Cancer Biol. Ther. 4 (2005) 753-758.

[188] J. Joseph, B. Niggemann, K.S. Zaenker, F. Entschladen, The neurotransmitter gamma-aminobutyric acid is an inhibitory regulator for the migration of SW 480 colon carcinoma cells, Cancer Res. 62 (2002) 6467-6469.

[189] C. Sarkar, D. Chakroborty, U.R. Chowdhury, P.S. Dasgupta, S. Basu, Dopamine increases the efficacy of anticancer drugs in breast and colon cancer preclinical models, Clin. Cancer Res. 14 (2008) 2502-2510.

[190] K. Masur, B. Niggemann, K.S. Zanker, F. Entschladen, Norepinephrine-induced migration of SW 480 colon carcinoma cells is inhibited by beta-blockers, Cancer Res. 61 (2001) 2866-2869.

[191] H.P. Wong, L. Yu, E.K. Lam, E.K. Tai, W.K. Wu, C.H. Cho, Nicotine promotes cell proliferation via alpha7-nicotinic acetylcholine receptor and catecholamine-synthesizing enzymes-mediated pathway in human colon adenocarcinoma HT-29 cells, Toxicol. Appl. Pharmacol. 221 (2007) 261-267.

[192] A. Cucina, S. Dinicola, P. Coluccia, S. Proietti, F. D'Anselmi, A. Pasqualato, M. Bizzarri, Nicotine stimulates proliferation and inhibits apoptosis in colon cancer cell lines through activation of survival pathways, J. Surg. Res. 178 (2012) 233-241.

[193] J.P. Raufman, K. Cheng, N. Saxena, A. Chahdi, A. Belo, S. Khurana, G. Xie, Muscarinic receptor agonists stimulate matrix metalloproteinase 1-dependent invasion of human colon cancer cells, Biochem. Biophys. Res. Commun. 415 (2011) 319-324.

[194] A. Belo, K. Cheng, A. Chahdi, J. Shant, G. Xie, S. Khurana, J.P. Raufman, Muscarinic receptor agonists stimulate human colon cancer cell migration and invasion, Am. J. Physiol. Gastrointest. Liver Physiol. 300 (2011) G749-760.

[195] D.J. Drucker, P. Erlich, S.L. Asa, P.L. Brubaker, Induction of intestinal epithelial proliferation by glucagon-like peptide 2, Proc. Natl. Acad. Sci. U. S. A. 93 (1996) $7911-7916$

[196] J. Thulesen, B. Hartmann, K.J. Hare, H. Kissow, C. Ørskov, J.J. Holst, S.S. Poulsen, Glucagon-like peptide 2 (GLP-2) accelerates the growth of colonic neoplasms in mice, Gut 53 (2004) 1145-1150.

[197] S. Trivedi, S.C. Wiber, H.M. El-Zimaity, P.L. Brubaker, Glucagon-like peptide-2 increases dysplasia in rodent models of colon cancer, Am. J. Physiol. Gastrointest. Liver Physiol. 302 (2012) G840-849.

[198] V. Kannen, S.B. Garcia, H. Stopper, A.M. Waaga-Gasser, Glucagon-like peptide 2 in colon carcinogenesis: possible target for anti-cancer therapy? Pharmacol. Ther. 139 (2013) 87-94.

[199] K. Yoshinaga, B.M. Evers, M. Izukura, D. Parekh, T. Uchida, C.M. Townsend Jr., J.C. Thompson, Neurotensin stimulates growth of colon cancer, Surg. Oncol. 1 (1992) 127-134.

[200] K. Iwase, B.M. Evers, M.R. Hellmich, H.J. Kim, S. Higashide, D. Gully, C.M. Townsend Jr., Indirect inhibitory effect of a neurotensin receptor antagonist on human colon cancer (LoVo) growth, Surg. Oncol. 5 (1996) 245-251.

[201] J.J. Maoret, Y. Anini, C. Rouyer-Fessard, D. Gully, M. Laburthe, Neurotensin and a non-peptide neurotensin receptor antagonist control human colon cancer cell growth in cell culture and in cells xenografted into nude mice, Int. J. Cancer 80 (1999) 448-454.

[202] J.M. Bugni, L.A. Rabadi, K. Jubbal, I. Karagiannides, G. Lawson, C. Pothoulakis, The neurotensin receptor-1 promotes tumor development in a sporadic but not an inflammation-associated mouse model of colon cancer, Int. J. Cancer 130 (2012) $1798-1805$.

[203] K. Bakirtzi, M. Hatziapostolou, I. Karagiannides, C. Polytarchou, S. Jaeger, D. Iliopoulos, C. Pothoulakis, Neurotensin signaling activates microRNAs-21 and -155 and Akt, promotes tumor growth in mice, and is increased in human colon tumors, Gastroenterology 141 (2011) 1749-1761 (e1741).

[204] J.R. Upp, P. Singh, C.M. Townsend, J.C. Thompson, Clinical significance of gastrin receptors in human colon cancers, Cancer Res. 49 (1989) 488-492.

[205] A. Aly, A. Shulkes, G.S. Baldwin, Gastrins, cholecystokinins and gastrointestinal cancer, Biochim. Biophys. Acta 1704 (2004) 1-10.

[206] G.D. Ciccotosto, A. McLeish, K.J. Hardy, A. Shulkes, Expression, processing, and secretion of gastrin in patients with colorectal carcinoma, Gastroenterology 109 (1995) 1142-1153.

[207] H. Ohkura, K. Hanafusa, K. Maruyama, H. Kitaoka, S. Watanabe, T. Kameya, Gastrin-enhanced tumor growth of a xenotransplantable human gastric carcinoma in nude mice, Jpn. J. Clin. Oncol. 10 (1980) 255-263.

[208] O.E. Winsett, C.M. Townsend Jr., E.J. Glass, J.C. Thompson, Gastrin stimulates growth of colon cancer, Surgery 99 (1986) 302-307.

[209] S. Watson, L. Durrant, D. Morris, Gastrin: growth enhancing effects on human gastric and colonic tumour cells, Br. J. Cancer 59 (1989) 554-558.

[210] N.M. Hoosein, P.A. Kiener, R.C. Curry, L.C. Rovati, D.K. McGilbra, M.G. Brattain, Antiproliferative effects of gastrin receptor antagonists and antibodies to gastrin on human colon carcinoma cell lines, Cancer Res. 48 (1988) 7179-7183.

[211] G.J. Krejs, Physiological role of somatostatin in the digestive tract: gastric acid secretion, intestinal absorption, and motility, Scand. J. Gastroenterol. Suppl. 119 (1986) 47-53.

[212] A.P. Savage, J.L. Matthews, T.E. Adrian, M.A. Ghatei, T. Cooke, S.R. Bloom, Effect of a long-acting analogue of somatostatin, SMS 201-995, on the development of 
intestinal tumours in azoxymethane-treated rats, Carcinogenesis 8 (1987) 561-563.

[213] D.Y. Dy, R.H. Whitehead, D.L. Morris, SMS 201.995 inhibits in vitro and in vivo growth of human colon cancer, Cancer Res. 52 (1992) 917-923.

[214] F. Hohla, S. Buchholz, A.V. Schally, A. Krishan, F.G. Rick, L. Szalontay, A. Papadia, G. Halmos, F. Koster, E. Aigner, C. Datz, S. Seitz, Targeted cytotoxic somatostatin analog AN-162 inhibits growth of human colon carcinomas and increases sensitivity of doxorubicin resistant murine leukemia cells, Cancer Lett. 294 (2010) 35-42.

[215] M. El-Salhy, Effects of triple therapy with octreotide, galanin and serotonin on a human colon cancer cell line, Oncol. Rep. 13 (2005) 45-49.

[216] M. El-Salhy, B. Sitohy, Triple therapy with octreotide, galanin and serotonin induces necrosis and increases apoptosis of a rat colon carcinoma, Regul. Pept. 108 (2002) 55-62.

[217] M. El-Salhy, B. Sitohy, Ö. Norrgård, Triple therapy with octreotide, galanin, and serotonin reduces the size and blood vessel density and increases apoptosis of a rat colon carcinoma, Regul. Pept. 111 (2003) 145-152.

[218] M. El-Salhy, Triple treatment with octreotide, galanin and serotonin is a promising therapy for colorectal cancer, Curr. Pharm. Des. 11 (2005) 2107-2117.

[219] H. Iishi, M. Tatsuta, M. Baba, H. Uehara, H. Yano, A. Nakaizumi, Chemoprevention by galanin against colon carcinogenesis induced by azoxymethane in Wistar rats, Int. J. Cancer 61 (1995) 861-863.

[220] K.Y. Kim, M.K. Kee, S.A. Chong, M.J. Nam, Galanin is up-regulated in colon adenocarcinoma, Cancer Epidemiol. Biomark. Prev. 16 (2007) 2373-2378.

[221] K. Nagayoshi, T. Ueki, K. Tashiro, Y. Mizuuchi, T. Manabe, H. Araki, Y. Oda, S. Kuhara, M. Tanaka, Galanin plays an important role in cancer invasiveness and is associated with poor prognosis in stage II colorectal cancer, Oncol. Rep. 33 (2015) 539-546.
[222] B.F. King, Purinergic signalling in the enteric nervous system (an overview of current perspectives), Auton. Neurosci. 191 (2015) 141-147.

[223] B.D. Gulbransen, K.A. Sharkey, Purinergic neuron-to-glia signaling in the enteric nervous system, Gastroenterology 136 (2009) 1349-1358.

[224] J.A. Roberts, M.K. Lukewich, K.A. Sharkey, J.B. Furness, G.M. Mawe, A.E. Lomax, The roles of purinergic signaling during gastrointestinal inflammation, Curr. Opin. Pharmacol. 12 (2012) 659-666.

[225] K. Nurgali, J.B. Furness, M.J. Stebbing, Analysis of purinergic and cholinergic fast synaptic transmission to identified myenteric neurons, Neuroscience 116 (2003) 335-347.

[226] K.J. LePard, J.J. Galligan, Analysis of fast synaptic pathways in myenteric plexus of guinea pig ileum, Am. J. Phys. 276 (1999) G529-538.

[227] P. Hofman, J. Cherfils-Vicini, M. Bazin, M. Ilie, T. Juhel, X. Hebuterne, E. Gilson, A. Schmid-Alliana, O, Boyer, S. Adriouch, V. Vouret-Craviari, Genetic and pharmacological inactivation of the purinergic P2RX7 receptor dampens inflammation but increases tumor incidence in a mouse model of colitis-associated cancer, Cancer Res. 75 (2015) 835-845.

[228] K.D. Lillemoe, J.L. Cameron, H.S. Kaufman, C.J. Yeo, H.A. Pitt, P.K. Sauter, Chemical splanchnicectomy in patients with unresectable pancreatic cancer. A prospective randomized trial, Ann. Surg. 217 (1993) 447-455 (discussion 456447).

[229] G.Y. Wong, D.R. Schroeder, P.E. Carns, J.L. Wilson, D.P. Martin, M.O. Kinney, C.B. Mantilla, D.O. Warner, Effect of neurolytic celiac plexus block on pain relief, quality of life, and survival in patients with unresectable pancreatic cancer: a randomized controlled trial, JAMA 291 (2004) 1092-1099.

[230] M. Di Giovangiulio, S. Verheijden, G. Bosmans, N. Stakenborg, G.E. Boeckxstaens, G. Matteoli, The neuromodulation of the intestinal immune system and its relevance in inflammatory bowel disease, Front. Immunol. 6 (2015) 590. 